\title{
A Balatonlelle-Rádpusztai Árpád-kori telep
}

\author{
MOLNÁR ISTVÁN és SIPOS CARMEN \\ Rippl-Rónai Múzeum, H-7400 Kaposvár, Fő u. 10. \\ E-mail: molnaristvan74@yahoo.com,carmensipos@yahoo.com
}

Molnar I. Sipos C.: Arpadian-aged settlement in BalatonlelleRádpuszta

Abstract: The article summarizes the results of the excavations of the Arpad-aged settlement from the 11th-14th century in Balatonlelle-Rádpuszta. We found a pit-house and several outdoor-furnaces with abundant finds: potteries, a spur and a mammut-tooth.

Keywords: Arpadian-aged village, pit-house, outdoor furnace, spur, mammut-tooth.

Tanulmányunkban a Rádpuszta mellett, a 67-es elkerülő út építése előtt 2005-ben és 2006-ban végzett megelőző feltárások során előkerült középkori településmaradványokat szeretnénk bemutatni. Ezek két lelőhelyet érintettek - a 67/5. Balatonlelle-RádpusztaRomtemplom mellett lelőhelyen Sipos Carmen és Molnár István, a 67/4. Balatonlelle-Rádpuszta-Temetőalja -dűlő lelőhelyen Honti Szilvia és Németh Péter Gergely vezette a feltárást. Utóbbiaknak köszönjük, hogy anyagukat feldolgozásra átadták. ${ }^{1}$

A Somogy Megye északi részén, a Balatonhoz közel található Rádpuszta település a környezetétől 1015 m-re emelkedő homokháton helyezkedik el. (1. kép) A dombháttól nyugatra, a mai napig használt temetőben, a település utolsó házaitól délnyugatra állnak a falu egykori templomának maradványai. Ez a megye egyik legszebb romtemploma, falai 8-10 m magasan megmaradtak. (12. tábla 6 . kép)

A településtől keletre fokozatosan emelkedő dombokon szőlő terem, nyugaton az észak-déli irányú Tetves patak és mocsaras ártere található. A patak az újkorban szabályozáson esett át, részben mesterségesen kialakított árokban folyik a Balatonba a Szemesi-berken keresztül. Ez utóbbi egy nagyobb, tölcsér alakú, mocsaras öböl, amely majd négy kilométer széles a torkolati részén, dél felé fokozatosan keskenyedik. A 67-es elkerülő út ezen a szakaszon a pataktól keletre fut, a tele-

1 Köszönjük az ásatás minden dolgozójának a munkát. Az SMMI dolgozói közül technikusként Mészáros Szilvia, Beke Zsolt, Varga Gyula, illetve Nyári Zsolt, Balla Krisztián, Cserép Tamás, Gál Zoltán, Ferencz Bálint és Ambrus Edit dolgoztak az ásatásokon. A gépi munkát a Leveller Kft., az ásatási munkásokat az Arch-Homo 2003 Kft. és a Leveller Kft. biztosította, a térinformatikai munkát az Archeodata $98 \mathrm{Bt}$ végezte. A tanulmányunkban leközölt fémanyagot Horváth Péter, a kerámiaanyagot Nagy Ágnes restaurálta, a tárgyrajzokat Nyári Zsolt, a tárgyfotókat Balla Krisztián készítette munkájukat köszönjük. A67-es útkorrekció Látrány-Balatonszemes közötti szakaszának régészeti munkálatait az Nemzeti Autópálya Zrt. anyagi támogatása és az akkori, kulturális örökségünk és múltunk emlékeinek védelme szempontjából megfelelöbb törvényi háttér tette lehetővé.

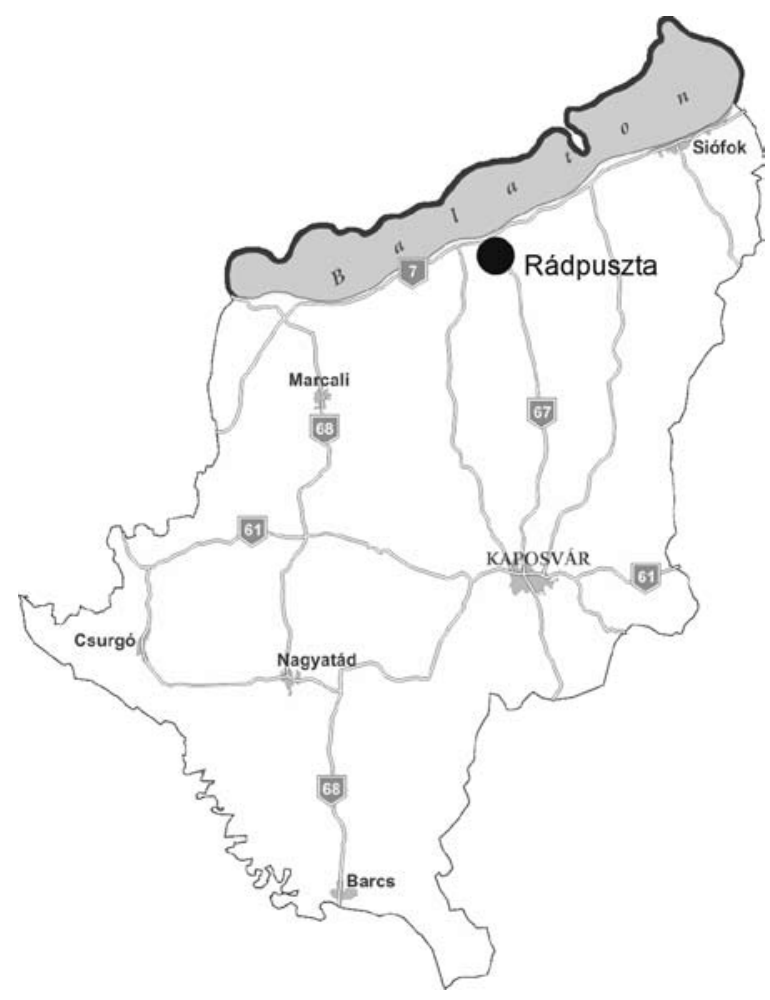

1. kép: A lelöhely elhelyezkedése

pülést nyugatról kerüli el (2. kép). A szemesi szakaszon még mocsaras területen vezet át, de a csomóponttól indulva fokozatosan eléri a berekpartot.

A kiváló megtelepedést nyújtó berekparton végig lelőhelyek sora húzódik. Rádpuszta település déli részétől északra haladva közel két kilométer hosszan folyamatosan régészeti objektumok kerültek felszínre. A terület négy lelőhelyre lett osztva. Ezek közül a két északi (67/2. Balatonlelle-Rádi út mellett és 67/3. Balatonlelle-Rádidomb) feltárásakor nem kerültek elő középkori objektumok. ${ }^{2}$ Ezek a mai Rádpuszta település mellett található 67/4. Balatonlelle-Rádpuszta-Temetőalja-dűlő lelőhely közepétöl jelennek meg, majd a legdélebbi lelőhelyen - 67/5. Balatonlelle-Rádpuszta-Romtemplom mellett a középkori templomrom közelében is folytatódnak.

A templomromnál Éry István 1959-ben végzett régészeti feltárást, ekkor a rom állagmegóvása is megtörtént. A templomnál 3 építési periódust különböztetett

2 Honti et al. 2006. 46-49 


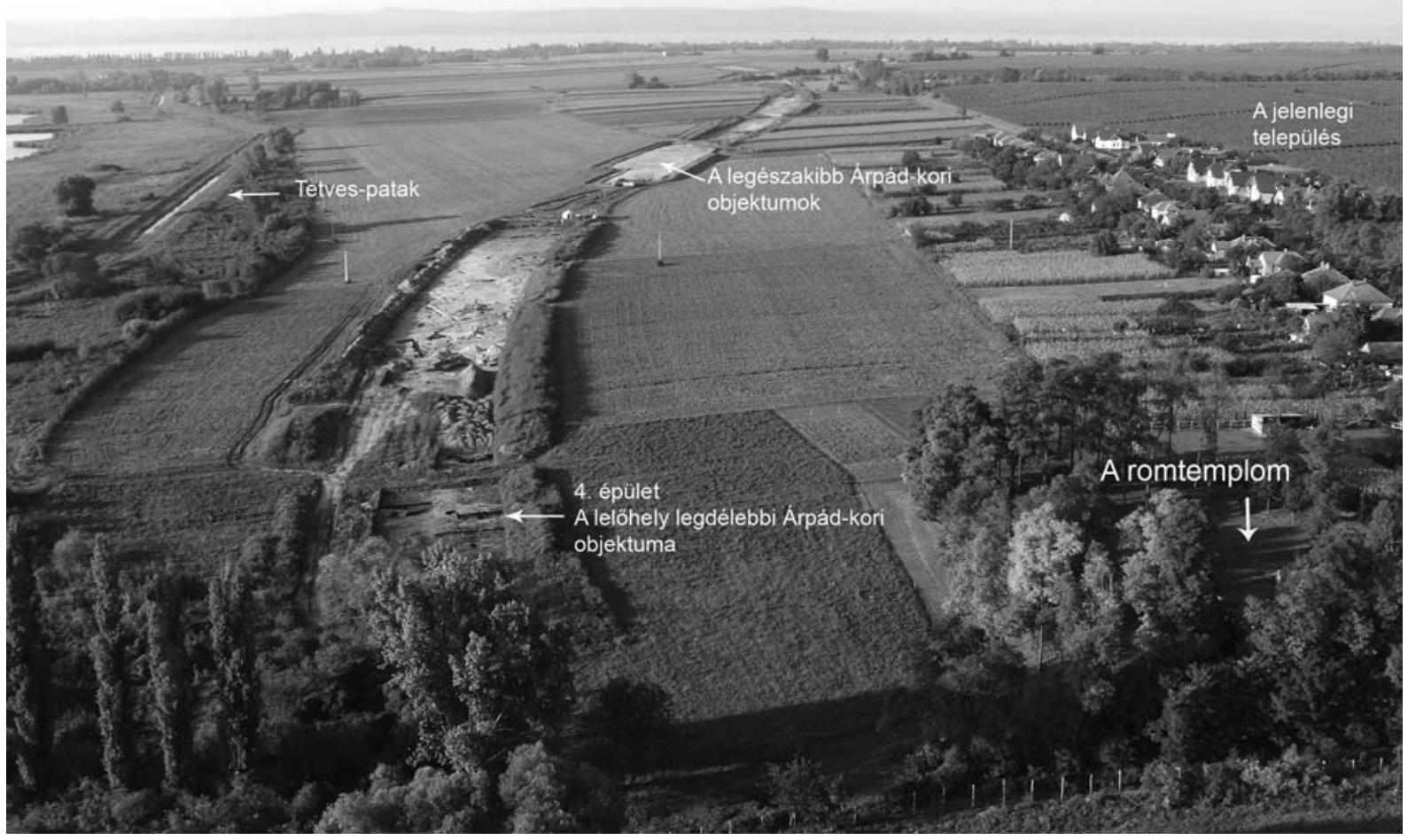

2. kép: légifotó a lelőhelyről

meg. A legkorábbi fázist az Árpád-korra tette, azon belül a 12. század közepére valószínüsítette, a 2. építési periódust a 13-14. sz. fordulójára, a 14. századra, a 3. periódust a 15 . század második felére keltezte. ${ }^{3} \mathrm{Az}$ épület az 1. periódusban félköríves záródású, kis téglatemplom volt, amely a 2. periódusban új hajót kapott, a régi templomból szentély lett. Az új, nagyobb méretü hajó nyugati karzattal, támpillérekkel rendelkezett, később sekrestyét építettek hozzá, ebben oltár is volt, kápolnaként szolgált. ${ }^{4}$

A település neve a Rád nemzetségre utal. A Rád nemzetség Vecelin és a fia Rád leszármazottait jelenti, akik Somogyban, a legyőzött Koppány területén kaptak birtokokat. Éry István a feltárás eredményeit bemutató cikkében összegyűjtötte és bemutatta a településre vonatkozó írott forrásokat is. A korai időszakból több, a pannonhalmi apátság javára tett adományról maradtak fenn adatok. 1131-1141 között András remete, korábbi veszprémi prépost rádi szabadosokat, 6 szőlömüvest és 3 szőlőt, 1146-ben Szines asszony 5 szölőt 5 háznéppel ajándékoz az apátságnak. Az 1237-40es Albeus-féle összeírás alapján tudjuk, hogy 10 ház szőlőmüvese, 1 jobbágya volt Rádon az apátságnak. 1255-ben a Rád nemzetség tagjai 30 hold földet adnak el az apátságnak. Később, a 14. századból vannak arra adatok, hogy Rád nemzetség tagjai bérlik a pannonhalmi apátság itteni földjeit. A források alapján Éry a Rád

3 Éry 1967. 190-193.

4 Éry 1967. 186-189. nemzetségben találja meg a település első birtokosait és a templom építőit, kegyurait, de a Pannonhalmi apátság szerez itt adományként birtokokat. Magyar Kálmán a templomot korai eredetűnek, Vecelin és leszármazottai kegyúri bencés egyházának tartja ${ }^{5}$. A templom és a település is megérte a török-kort. $A z$ 1573-75-ös török összeírásokban még szerepel, 8 házat említenek. Később elnéptelenedik, csak majorság lesz a falu helyén a visszahódítás után. ${ }^{6}$

A templomot 1333-ban, a pápai tizedjegyzékben említik először, ekkor 50, a 1335-ös összeírásban 20 dénárral szerepel, a papot Péternek illetve Gergelynek hívják. 1419-ből István, 1517-ből Kelemen nevű plébános neve maradt fenn. A Somogyi föesperességhez tartozott, Szűz Máriának szentelték. ${ }^{7}$

Ha nem is teljes biztonsággal, de egy fontos történelmi esemény is a településhez kapcsolható. Az Imre király és öccse, a későbbi II. András közötti testvérháború egyik csatája 1199-ben Rádon zajlott. A harc Imre győzelmével ért véget. $A$ több Rád nevű helység közül a kutatás leginkább ide, a Somogy megyei Rádra lokalizálja a csata helyét. ${ }^{8}$

A források jól mutatják a szőlőművelés nagy múltját a településen, már a legkorábbi említés is ezzel kapcsolatos. A falutól keletre ma is szőlöhegyek kezdődnek. A források alapján azt is valószínüsíthetjük, hogy tatár-

\footnotetext{
$5 \quad$ Magyar 2001. 265.

Éry 1967. 189-190.

Éry 1967. 189., M. Aradi 2007. Adattár

8 Kristó 2003. 130., Kristó 2006. 197.
} 
járás sem okozhatott nagy törést a település életében. Tudjuk, hogy Rád a 12. század végén a hadiút mellett feküdt, amely Szemesen, Gamáson és Marcalin át futott. ${ }^{9}$ Egy másik, Rádot is érintő út kelet felé, Teleki, Ozora és Simontornya irányába vezetett. Rádtól nyugatra a bereken átkelve a Balaton déli partján folytatódott az út, amely az északi partra átjutást biztosító átkelőt is érintett. ${ }^{10}$

Lázár deák 16. század elején készült térképén a település nincs ábrázolva, a mai Somogytúrnál lévő Tard, Nagycsepely, Köröshegy van jelölve a térképen. Csepely a Balaton mellé van rajzolva, a tó illetve a mellette lévő mocsaras, lápos területek igen kiterjedtek voltak. A kutatás a Balaton vízszintjének emelkedését, a vízfelület kiterjedését valószínűsíti az időszakban. ${ }^{11}$ Ennek okát elsősorban az éghajlati változásban kereshetjük. Az írott források is utalnak az éghajlat 13. századtól bekövetkező csapadékosabbá válására, a vizes térszintek kiterjedésére. ${ }^{12}$ Mint majd kitérünk rá, erre lelöhelyünkön is vannak jelek. Ugyanakkor - legalábbis egyes vélemények szerint - a Balaton Árpád-kor végi gyors vízszintemelkedésében egy a Tihanyi apátság által a 13. század első felében végzett gátépítés is szerepet játszhatott. ${ }^{13}$

$A z$ első katonai felmérésen a berket még igen kiterjedtnek ábrázolják, szinte a templomig tart. A templom természetesen romként van ábrázolva, nem jeleztek települést, de több épület látszik. Ezek nem a település mostani helyén, hanem keletre, a domboldalon vannak. A településtől délre az útviszonyok hasonlóak, mint napjainkban. A patak partján is fut egy út, valamint a ma is létező (ekkor szőlőkel teli), erdőben futó Viszre menő út is ábrázolva van. Az épületek ez utóbbihoz települtek. Északon a ma már csak alárendeltnek számító, két északkeleti irányú szemesi út létezett, a 20. század végi észak-déli út még nem. Jól látszik egy út a berken keresztül, amely a mocsaras részen át vezetett, ettől délebbre ugyan volt több átjáró, de ettől északra nem. A település helye bizonyára összefüggésben van ezzel. Úgy látszik itt lehetett a legjobb, legészakibb átkelési lehetőség a berken.

A 2. katonai felmérésen Puszta Rádiként szerepel. A berek visszaszorult, a gazdasági viszonyok hasonlóak lehettek, mint most. A templom körüli részen legelő, attól északabbra müvelt terület látszik. Az útviszonyok hasonlóak az első felméréshez, a gazdasági épületek is hasonló helyen voltak. Ezen jól látszik a berken átvezető, kiépítettebbnek tűnő út. A helyiek elmondása alapján néhány évtizeddel ezelőttig szekérrel járható töltés vezetett a mocsáron át. A középkori településnél sűrű római telep került feltárásra. Az intenzív római kori jelenlét is egy átkelöre utal. Ekkor is a mocsár összeszükülő részén vezethetett át a Balaton partján futó kelet-nyugati út. ${ }^{14} \mathrm{~A}$ dombok és a berek közötti terület ősidőktől von-

9 Glaser 1932. 1-2.

10 Glaser 1929. 266., 270

11 Bendefy-Nagy 1969. 52., 62-65., Mészáros-Serlegi 2011. 217222., Szalóky-Bódis 2004. 279. Utóbbi tanulmány a lelöhelyünktől nyugatra lévő Szemesi-Berek élővilágával foglalkozik.

12 Rácz 2006. 44

13 Bendefy-Nagy 1969. 52., 62-65., Szalóky-Bódis 2004. 279.

14 Honti et al. 2006. 46. zotta a megtelepülöket, ugyanakkor a földrajzi helyzet egy keskenyebb sávra szükíti a megtelepedés lehetséges területét. A berken átvezető átjáró is hozzájárult a település létrejöttéhez.

Mint már utaltunk rá, a 67-es út nyomvonala a falutól nyugatra fut, a lelőhelynek az út nyomvonalába eső része volt feltárható. A mai település a tengerszint felett 113-122 m-re van, a Tetves patak mocsarasodó ártere 106-108 m mélységig mélyül. Nyilvánvalóan ez a terület nagyon érzékeny volt a talajszint változásaira. Maga az ásatási terület a legdélebbi pontján $108 \mathrm{~m}$ tengerszintfeletti magasságon kezdődik és északra haladva egyre magasabban fekvő területet érint. Amikor a nyomvonal a mai településhez fokozatosan közeledni kezd, lendületesebben emelkedik 112-113 m magasságig. Bár a folytatódó nyomvonal egyre magasabban halad, az utolsó Árpád-kori, középkori objektumok nagyjából a jelenlegi település utolsó házainál, az előbbi magasságban voltak. Az itt talált kemencebokortól 60 m-re délre, egy nagyjából 100 m hosszú szakaszon csoportosult az objektumok többsége, 3 kemence és 4 egyéb objektum. A legdélebbi, legmélyebb részen volt egy ház, egy kemencebokor és egy sekély gödör, valamint a két terület között elszórtan három gödör. Mivel a nyomvonal egy ivet ír le, az ásatás területe a mai országúttól - amelynek két oldalán a település házai vannak - délen 195 m-re, a középső részén kb. 210 m-re, az északi, legközelebbi részén 175-178 m-re van. Keletre, azaz a mai település felé is emelkedik a tengerszint feletti magasság. (2. és 3. kép)

A lelőhelyen az Árpád-kori objektumok előfordulása a tengerszint feletti magassággal és az egykori település feltételezett központjához való közelséggel magyarázható. $A$ lelőhely legdélebbi része igen mélyen van, de a településhez és a templomhoz való közelsége magyarázza az objektumok sűrüsödését. A templom a mai településtől délnyugatra, a dombhát kinyúlásában, 110-111 m tengerszintfeletti magasságon van, ehhez fut közel a nyomvonal - a templomot 70-75 m-re közelítve meg.

A korabeli vízügyi helyzet alapvetően megszabhatta a település lehetséges helyét. Erre szép példát találunk a lelőhely többi régészeti korszakát vizsgálva. A67/5. lelöhely déli részén, a legmélyebb területen csak az Árpád-kor és a késő bronzkor (Urnamezős-kultúra) objektumait találjuk. Majd a római objektumok jelennek meg, elöször egy sír majd nagyobb mennyiségü telepobjektum, amelyek végighúzódnak mindkét lelőhelyen. $A z$ 5. lelőhely középső és északi, azaz magasabban fekvő részén a rézkori (Balton-Lasinja, Badeni) és avar, majd még északabbra és magasabban, a 67/4. lelőheIyen a neolitkum (Dunántúli Vonaldíszes Kultúra) illetve bronzkor korábbi időszakaira keltezhető (SomogyvárVinkovci kultúra, Kisapostagi kultúra), objektumok is megjelennek.

Sajnos pont a legdélebbi, legmélyebben fekvő területen volt a legnehezebb a feltárás. A fekete mocsári altalajban nehéz volt az objektumokat megtalálni - sokszor csak az erősen kevert, paticsos betöltés árulkodott, ráadásul jól megfigyelhető volt, hogy ez a talaj fedett is 


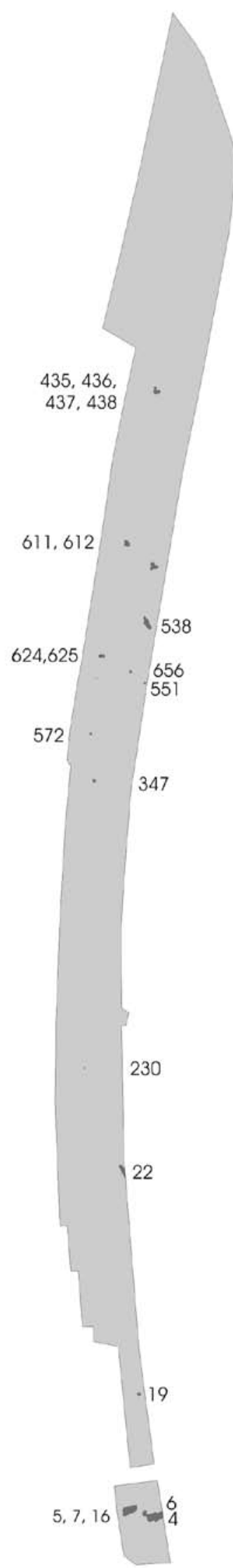

3. kép: a középkori objektumok elhelyezkedése objektumokat. Ez a berek területének folyamatos változásával magyarázható - a mai állapotánál több alkalommal is kiterjedtebb mocsár újra és újra beborította, felülrétegezte a területet. Egy elsősorban római és Urnamezős kerámiával és késő bronzkori bronztűkkel teli barnásfekete rétegbe ásták az Árpád-kori objektumokat. Bár az autópályás feltárás lehetőségeihez képest igyekeztünk az objektumokat megtalálni, kutatóárkokat húztunk, a talajt változó mélységben szedtük le, így is bizonyára veszhettek el régebbi objektumok. Azt mindenesetre elmondhatjuk, hogy az Urnamezős-kultúra időszakában, a Római korban és az Árpád-kor korábbi szakaszában lakhatóak voltak a mélyebb területek is. $\mathrm{Az}$ ásatás során, a legdélebbi részen a nyári kánikulában nem okozott komoly gondot a talajvíz, de egy jelentősebb eső után már víz alá került ez a terület. Ez a rész nem igazán lakható korunkban. Mezőgazdasági müvelés sem folyik itt, legelőnek használják, a katonai felmérések térképei alapján ez az újkorban nagyjából mindig is így volt.

A két lelőhelyen összesen - a kemencebokrokat egynek számolva - 14 Árpád-kori objektumot találtunk. A valós szám ennél nagyobb lehet, azonban a lelőhelyen található igen intenzív és edényégető kemencéket is tartalmazó ${ }^{15}$ római telep anyaga szinte mindent beborított. Az Árpád-korinak bizonyult objektumok kerámiaanyagának is jó része római volt, a kemenceplatnik alatt is találtunk római kerámiát. Feltételezhetjük, hogy Árpád-kori, de jól azonosítható leletanyagot nem tartalmazó objektumok is rómaiként lettek keltezve.

\section{Az objektumok leírása:}

\section{4. épület}

$A z$ épület a szelvény déli részében, az 5 . kemencétöl 5 m-re keletre, a keleti szelvényfalnál volt. Sajnos a barnásfekete „mocsári” altalajban nehezen volt megfogható. Az erősebben paticsos alsó rétegei jól elkülönültek, de máshol, több helyen túl lett bontva.

A téglalap alakú, nagyobb méretű, kb. 250×370 cm-es nagyságú épület a nyesett felszíntöl $70 \mathrm{~cm}$-re mélyült. ${ }^{16}$ Meredeken szükülő falú, vízszintes aljú. Az északnyugati sarkában volt a kemencéje. Az épület kb. NyDNy - KÉK-i tájolású. Nyugaton volt az épület - nagyjából másfél méter hosszan követhető meneteles bejárata. Sajnos ez volt a legnehezebben megfigyelhetö, túl lett bontva az oldalain és az alján is. A metszetfalon már jobban látszott eredeti, lejtős formája. A kemence az épület északnyugati sarkában, a bejáratnál állt. Félig bevájt lehetett, a ház gödréből kissé kilógott, a belső része talán épített volt. Platnija $105 \mathrm{~cm}$ átmérőjü, a ház aljával egy szintben volt. A falából csak egy helyen maradt meg néhány $\mathrm{cm}$. A platni kb. $1 \mathrm{~cm}$-en szürkésbarnára, keményre égett, alatta $5 \mathrm{~cm}$ vastag vörösre égett réteg volt. Hőtartó rétege nem volt.

A ház középső részén, - a keleti oldalhoz közelebb - kb. $35 \mathrm{~cm}$ átmérőjü $35 \mathrm{~cm}$ mély cölöplyuk volt. Az oldala erősen átégett, ez talán a ház leégésének nyoma. A nyugati rövid oldal közepénél $15 \mathrm{~cm}$ átmérőjü, $15 \mathrm{~cm}$ mély kerek cölöplyuk volt,

15 Honti et al. 2006.49-56

16 Az objektumok mélységét a továbbiakban is a nyesett felszínhez viszonyítva igyekszünk megadni. Természetesen ez nem azonos a korabeli felszínnel, de - már a lelőhely nagy domborzati különbségei miatt is - úgy véljük, hogy az abszolút adatoknál sokkal jobban jelzi az egyes objektumok mélységét. 
a keleti oldalon nem került elő párja. A lejáratnál ovális alakú, rézsűs falú, ívelt aljú, $\mathrm{kb} .40 \times 50 \mathrm{~cm}$ átméröjü, $20 \mathrm{~cm}$ mély cölöplyuk volt, a ház gödrétől kb. $60 \mathrm{~cm}$-re.

Betöltése sötétbarna, a mocsári altalajtól föleg faszenes, paticsos volta miatt elkülöníthető. A felső részen $(20-25 \mathrm{~cm}$ en) kissé faszenesebb volt a betöltése. $E$ réteg alatt, a felszíntöl 20-25 cm-re fehér, világosszürke hamus réteg volt. Ez 12 $\mathrm{cm}$ szélességben, $170 \mathrm{~cm}$ hosszan fut az objektum középső részénél. Alatta, a felszíntől $35-60 \mathrm{~cm}$-re $5 \mathrm{~cm}$ vastag faszénréteg volt. Alul, az objektum középső részén is található egy 3 $\mathrm{cm}$ vastag faszénsáv. Az objektum északnyugati sarkában kemence volt, ez elött kb. $30 \mathrm{~cm}$ magasan erősen faszenes - hamus - paticsos betöltés volt, ezt sárga löszös, paticsos sávok tagolják. A platni felett kb. $4 \mathrm{~cm}$ vastag paticsos omladékréteg - egykori boltozatának maradványa - volt. (10. tábla)

Az objektum igen böséges leletanyagot tartalmazott, amelynek nagyobb részét kora Árpád-kori kerámia jelentette. (1-2. tábla) Több edény nagyobb darabjai is előkerültek, ez alapján az edények formájáról is tudtunk információkat szerezni. Több apró kavicsos homokkal soványított edénynek enyhén kihajló, egyenesen levágott pereme volt. Ezek között - a díszítetlen töredékek mellett (13.10/4.1.3., 13.10/4.3.3.) $)^{17}$ - megtaláltuk egy csigavonaldíszes, vastag falú, nagyméretű fazék nagyobb töredékét (13.10/4.4.2.1.) is. Két halvány sárgásbarna színü, helyenként kormosra égett, vállán ferdén beszurkált - úgynevezett körömbenyomkodásos - sorral, alatta, az oldalán bekarcolt csigavonaldísszel díszített edény számos töredéke volt a betöltésben (13.10/4.2.1., 13.10/4.2.3., 13.10/4.2.8., 13.10/4.4.2.1-3.). Az egyik fazék peremátmérője $24 \mathrm{~cm}$ volt ${ }^{18}$. Egy vállán körömbenyomkodással díszített fazéknak kihajló, lekerekített, elkeskenyedő pereme volt (13.10/4.3.2.). Hasonló pereme volt egy csillámos homokkal soványított, nyakán bekarcolt díszítésü, vállban kiszélesedő, egyenes aljú, zömök, kis edénynek (13.10/4.4.1.). Ennek pereme $13 \mathrm{~cm}$ átmérőjü, a magassága $11,4 \mathrm{~cm}$ volt. Több, apró kavicsos homokkal soványított fazék kihajló pereme kissé megvastagodott. A perem lehet egyenesre vágott, mint egy díszítetlen, vörös töredéken, amely $25 \mathrm{~cm}$ átmérőjű edényből származik (13.10/4.2.4.) vagy lekerekített, mint egy szürkésbarna, vállán bekarcolt hullámvonaldíszes töredéken (13.10/4.2.9.). Néha ezeknél a kissé vastagodó peremeknél a fedő számára már hornyolatot, vájatot, alakítottak ki. Ezt tapasztaljuk egy csillámos homokkal soványított, világos vörösesbarna színü, kormosra égett, kihajló, fazéktöredéken, amelynek vállán sürün bekarcolt csigavonaldísz van, a perem átmérője $19 \mathrm{~cm}$ (13.10/4.1.1.). Két másik, homokkal és apróra zúzott kaviccsal soványított, téglavörös színü, nagyobb méretü, hasonló peremü fazék vállán bekarcolt hullámvonalköteg-dísz volt (13.10/4.2.5-6., 13.10/4.4.2.4.). Az edény $22-23 \mathrm{~cm}$ peremátmérőjű lehetett. Egy kisebb, kissé megvastagodó, kihajló fazékperem-töredéket bordával tagoltak (13.10/4.2.10.).

Sok díszítetlen alj- és oldaltöredék (13.10/4.1.10-13., 13.10/4.2.23., 13.10/4.3.4-5., 13.10/4.4.2.7-9., 13.10/4.4.2.2425.) mellett igen sok bekarcolt egyenes vonallal, csigavonallal díszített töredék volt az objektum betöltésében (13.10/4.1.2., 13.10/4.2.19, 13.10/4.1.5-9., 13.10/4.1.2., 13.10/4.2.11-16, 13.10/4.2.20., 13.10/4.3.8-10., 13.10/4.4.2.13., 13.10/4.4.2.1820., 13.10/4.4.2.22., 13.10/4.5.1., 13.10/4.4.2.26.). Több bekarcolt hullámvonaldíszes oldaltöredék is felszínre került (13.10/4.1.4.,13.10/4.1.6-7.,13.10/4.2.21.,13.10/4.4.2.23.).Számos egyenes vonalköteg-díszes fazékoldal-töredéket is találtunk (13.10/4.2.17-18., 13.10/4.2.22., 13.10/4.3.11., 13.10/4.4.2.15., 13.10/4.4.2.14-15., 13.10/4.4.2.21., 13.10/4.5.2.). Egy alkalom-

17 A leletanyag ismertetésénél zárójelben az SMMI leltárkönyvében szereplö azonosító-számokat közöljük.

18 Sajnos a kissé aszimmetrikus edényekböl származó töredékeknél a peremátmérök csak hozzávetőleges pontossággal kiszerkeszthetőek mal hullámvonalköteg és egyenes vonalköteg-dísz egyszerre jelentkezik (13.10/4.1.14.). Több rádlimintás töredék is volt a ház betöltésében (13.10/4.2.7., 13.10/4.4.2.12.). Egy barna, kormos nyaktöredéken ferdén beszurkált minta fut körbe, ez alatt csigavonal-dísz volt (13.10/4.3.6., 13.10/4.4.2.10-11.). Máshol a ferdén beszurkált sor alatt bekarcolt hullámvonalmintával díszített töredék található (13.10/4.3.7.). Előfordul egy sor hullámvonal alatt bekarcolt csigavonal töredéke (13.10/4.4.2.16.) is. Két fazékaljon volt fenékbélyeg (13.10/4.4.2.6., 13.10/4.4.2.27. - az utóbbi kereszt alakú volt).

Kevés bográcstöredéket találtunk. Az egyik homokkal és apró kaviccsal soványított, vörös felületü, szürke törésfelületü, helyenként kormosra égett cserépbogrács peremtöredéke. A külső oldalán kissé megvastagodó, szögletesre alakított pereme van, az oldalán csigavonallal díszítették (13.10/4.2.2.). $24 \mathrm{~cm}$ lehetett a peremátmérője. Egy másik hasonló anyagú és színű bográcsnak kihúzott, $2,5 \mathrm{~cm}$ vastagságú pereme volt (13.10/4.3.1.).

Több fémtárgy is volt az épület feltöltésében. (3. tábla). Sarkantyú töredékeit találtuk meg, az egyiken megmaradt a sarkantyúvég, ahol kettőskónikus korongon volt a tüske. Megmaradt a sarkantyú felfüggesztésre szolgáló része is, ez nagyjából ovális alakú, rajta két lyukkal (3.10/4.2.28. - 3. tábla, 12. tábla 2. kép) Egy nyéltüskés sarló töredéke (13.10/4.3.13.), és egy köpüs, szakállas nyílhegy volt még a fémanyagban (13.10/4.5.3.).

Több megmunkált kő volt az objektumban, közte egy fenőkő töredéke (13.10/4.2.26), egy őrlőkő darabja (13.10/4.4.2.30) és több nehezen azonosítható töredék (13.10/4.2.27., 13.10/4.4.2.33.). Több római tégla és tegula darab (13.10/4.4.2.28-29, 13.10/4.4.2.32-33), áglenyomatos paticsdarabok (13.10/4.3.12.) és átfúrt agyagnehezék töredéke (13.10/4.2.25.), valamint több nagyobb méretü fémsalak-darab (13.10/4.4.2.34.) is volt a betöltésben.

Nagyobb mennyiségü állatcsontot találtunk, közte nagy lábszárcsontok, állatfog, kecskeszarv is volt. A leletanyag talán legérdekesebb, legszokatlanabb része egy mamutfog töredéke.(13.10/4.2.24. - 12. tábla 5. kép)

\section{5. és 7. kemence, 16. elötérgödör}

A kemencebokor a szelvény déli részén volt, az elöbbi épülettől 5 méterre nyugatra. A fekete „mocsári” altalajban oldala nehezen volt megfogható.

\section{6. elötérgödör}

A nagyméretű, mély gödörhöz két kemence tartozott. Tájolása déldélnyugat-északészakkeleti, hasonló az épületéhez. Északkeletre az 5., délnyugatra a 7. kemence volt. Az előtérgödör szabálytalan vagy kissé szabálytalanra bontott - nyolcashoz közelítő - ovális alakú volt. A fala meredeken szükült, az alja ívelt, a közepe felé mélyült, a két kemencénél a legsekélyebb. $360 \mathrm{~cm}$ nagyságú, kb. $80 \mathrm{~cm}$-re mélyült a nyesett felszíntől, a platnik szintjétől $45-50 \mathrm{~cm}$-rel mélyebben volt. Betöltése sötétbarna-fekete, paticcsal kevert - a fekete „mocsári” talajban nem látszott jól. A két kemence előtt faszenes, paticsos betöltés volt. Alul egy sötétbarna iszapos réteg volt található. (10. tábla)

Leletanyaga: őskori, római (13.10/5.1.1-2.) és Árpád-kori (13.10/5.1.311.) kerámiatöredékek. Az utóbbiak között díszítetlen alj és oldaltöredékek mellett (13.10/5.1.6-7.) rádlidiszes (13.10/5.1.8-9.) és csigavonalas (13.10/5.1.10-11.) töredékek voltak. Homokkal és apróra zúzott kaviccsal soványított, szürkésbarna színű fazekak, enyhén kihajló, egyenesen levágott peremtöredékei is elökerültek. (13.10/5.1.3-5.). Az elötérgödörben talált megmunkált kő (13.10/5.1.10-12.) és számos állatcsont korát nem tudjuk megállapítani.

5. kemence

A 16. objektum északkeleti részén volt. Nagyobb méretű, kb. $130 \mathrm{~cm}$ átmérőjü, cipó alakú kemence, amelynek fala kb. $30-40 \mathrm{~cm}$ magasságban viszonylag jól megmaradt. A palást $\mathrm{kb} .5 \mathrm{~cm}$ vastagon égett át, az oldala nagy része megmaradt, 
a legfelső része hiányzott csak. A platni a nyesett felszín alatt 30-40 cm-re volt, nagyjából vízszintes. Egy centiméter vastagon keményre, szürkésbarnára, alatta vörösre égett. Bár sürün ki volt rakva kerámiákkal, a kerámiaréteg helyenként ritkás volt, a kemence szájánál hiányzott. Betöltése a platni felett erősen paticsos, fekete mocsári talaj.

Leletanyaga: a platni felett több Árpád-kori kerámiatöredék volt. Ebböl kiemelhető egy homokkal és kaviccsal soványított, korongolt, vörös színű, külső felületén vörösesbarna, megvastagodó, szögletes, enyhén kihúzott cserépbogrács peremtöredék (13.10/5.2.1.). Szintén a platni felett volt több csigavonalas (13.10/5.2.2.) illetve díszítetlen oldal- és aljtöredék (13.10/5.2.3.), valamint kevés állatcsont.

A kemence platni alatt nagy mennyiségủ kerámiát találtunk, ezek nagy része két edényböl származott, a maradékban több edény kisebb-nagyobb töredékei voltak (3-5. tábla). 65 darabból majdnem teljesen összeállítható volt - csak kis kiegészítésre szorult - egy apró kavicsos homokkal soványított, barna színü fazék. Pereme kihajló, egy bemélyített sávval kettéosztott, nyakán bekarcolt hullámvonallal díszített, ez alatt bekarcolt csigavonaldísz volt. A zömök edény peremátmérője $17,5 \mathrm{~cm}$, fenékátmérője $13,5 \mathrm{~cm}, 19 \mathrm{~cm}$ magas (13.10/5.3.1.- 4 tábla, 12. tábla 4. kép). 60 töredék egy homokkal és kaviccsal soványított, téglavörös színü, kormos, bekarcolt csigavonaldíszes fazékhoz tartozott. Ennek pereme kihajló, csak kissé megvastagodó, ferdén levágott, fedő számára profilált. A nagyméretű fazék a vállánál a legszélesebb. Peremátmérője $20 \mathrm{~cm}$, a fenékátmérő 13 $\mathrm{cm}$ (13.10/5.3.2.). Csillámos homokkal és kaviccsal soványított, szürkésfekete, kormos, kihajló, rádlimintából álló csigavonallal díszített nagyméretű fazekak töredékeit is megtaláltuk. Az egyik edénynek kissé megvastagodó, $19 \mathrm{~cm}$ átmérőjű peremet szerkeszthettünk ki. A rádlidisz már a perem alatt, a nyakon elkezdődik. (13.10/5.3.3.). A másik, hasonló díszű, nem vastagodó peremű edény peremátmérője $18 \mathrm{~cm}$ lehetett. (13.10/5.3.4.). A fentieken kívül is több peremtöredéket találtunk. Enyhén kihajló, egyenesen levágott, (13.10/5.3.9.) és fedő számára profilált peremü (13.10/5.3.7-8.) fazekak töredékei is voltak közöttük. Egy csillámos homokkal soványított, kormos felületű, vörösesbarna színū, kihajló, egyenesen levágott peremű fazék vállán ferdén beszurkált - úgynevezett körömbenyomkodásokból álló - sor fut körbe, alatta az oldalán bekarcolt, csigavonalas díszítés volt (13.10/5.3.6.). Aljtöredékek, díszítetlen (13.10/5.3.10-11.) és csigavonalas díszű oldaltöredékek (13.10/5.3.12-13.) is voltak a cseréprétegben. Külön kiemelést érdemel egy bordásnyakú edény töredéke. A csillámos homokkal és apró kaviccsal soványított, halvány szürkésbarna edény nyakánál széles borda fut körbe, a pereme hiányzik. A felületén sekélyen bekarcolt, széles csigavonal-szerű díszítés fut körbe. (13.10/5.3.5.) Egy egyenes oldalú kőtárgy töredéke is volt a platni alatt (13.10/5.3.14.) 7. kemence

A 16. objektum délnyugati végében volt. Nagyméretű, kb. $130 \mathrm{~cm}$ átmérőjủ kemence. Cipó alakú kupolája viszonylag jól - kb. $30 \mathrm{~cm}$ magasan - megmaradt, kb. $5 \mathrm{~cm}$ vastagon volt vörösre égve. A platni a nyesett felszínen volt, kissé északkeletre, az elötérgödör felé lejtett. A platni kemény, jól kiégett, felül szürkésbarnára, alatta vörösre égett, $\mathrm{kb} .7 \mathrm{~cm}$ vastag volt. Hőtartó rétegként kerámiát tettek alá. Felette erősen paticsos, omladékos, falmaradványos fekete betöltés volt.

Leletanyaga: a platni felett kevés állatcsont, kő, őskori, római (13.10/7.5-7.) és Árpád-kori kerámia. (5-7. tábla).

Utóbbiak között kihajló, egyenesen levágott (13.10/7.1.1.) és lekerekített végü (13.10/7.1.4.) peremtöredékek, hullámvonallal, alatta csigavonallal díszített (13.10/7.1.2.) és díszítetlen oldaltöredékek (13.10/7.1.3.) voltak

A platni sűrün ki volt rakva kerámiával. Ebből több kiegészíthető edény került elő. Nagy mennyiségủ töredékből kiegészíthető volt egy szürkésbarna színü, apró kaviccsal kevert, csillámos homokkal soványított, kihajló, egyenesen levágott peremű fazék. A válán ferdén beszurkált sorral, alatta egész felületén futó csigavonallal díszített edény valamivel a válla alatt a legszélesebb, a magassága $24,6 \mathrm{~cm}$, a peremátmérő $18,2 \mathrm{~cm}$, fenékátmérö $13 \mathrm{~cm}$. (13.10/7.2.22.- 6 tábla, 12. tábla 3. kép) Nagyobb mennyiségü - $55 \mathrm{db}$ - töredék egy csillámos homokkal és apró kaviccsal soványított, szürkésbarna színü, helyenként kormos felületű, kihajló, kissé megvastagodó, duzzadt, ívelten levágott, fedő számára profilált peremü fazékból származik. Az edény vállán körömbenyomkodással, alatta bekarcolt, az alj felé szélesedő közű csigavonallal díszített, a peremátmérője $15,6 \mathrm{~cm}$. (13.10/7.2.1.). A hőtartó rétegben több töredéke volt egy csillámos homokkal és kaviccsal soványított, szürkésbarna, helyenként kormos felületű, szélesen kihajló, külső oldalán kissé megvastagodó, egyenesen levágott peremü, egyenes aljú, rádlidíszes fazéknak. Az edény peremátmérője $17 \mathrm{~cm}$, a talp átmérője $12 \mathrm{~cm}$ volt (13.10/7.2.2., 13.10/7.2.5.). Egy kihajló, ívelten levágott peremú fazék több töredéke is a platni alá lett szórva, a fazék peremátmérője 17 cm lehetett (13.10/7.2.3.). Szélesen kihajló, ívelt (13.10/7.2.9.) és csak kissé megvastagodó, egyenesen levágott peremtöredékek (13.10/7.2.8., 13.10/7.2.10-11.) voltak a hőtartó rétegben. Az egyik szélesen bekarcolt sürü csigavonallal van díszítve (13.10/7.2.8.). Több peremtöredék a külső oldalán kissé vastagodik, kissé lefelé húzott, ívelten levágott (13.10/7.2.1213., 13.10/7.2.6-7.). Az egyik ilyen peremü, több darabból álló töredéken, az edény vállrészénél bekarcolt hullámvonaldísz található (13.10/7.2.6-7.) Több aljtördéket találtunk (13.10/7.2.14-16.). Három összetartozó töredékröl megállapítható volt, hogy 10,5 cm-es talpátmérőjü fazékból származik. (13.10/7.2.4.). Díszítetlen és csigavonallal díszített oldaltöredékek (13.10/7.2.17-19.) valamint római tál és fazéktöredékek $(13.10 / 7.2 .20-21$.) is voltak a hőtartó rétegbe tapasztva.

\section{6. gödör}

A szelvény déli részében, a 4. épület és a 16 . kemencebokor között, a 4. épület bejárati részétöl északnyugatra volt.

Sekély, ovális alakú, nagyobb objektum, fala meredek, az alja kissé egyenetlen volt. Nagyjából $280 \mathrm{~cm}$ átméröjü, 30-40 $\mathrm{cm}$ mély. Sötétbarna faszenes, paticsos betöltése nehezen volt megfogható a mocsári talajban. (10. tábla)

Leletanyag: 4 db csillámos homokkal és apró kaviccsal soványított, barna, kormos felületű, Árpád-kori kerámia töredék. Kettő fazék vállából (13.10/6.1.3-4.), egy másik az aljából (13.10/6.1.2.), származik. A gödör viszonylag kevés leletanyagának legjellemzőbb darabja egy kihajló, kissé megvastagodó, egyenesen levágott peremtöredék. Ez egy, a vállán körömbenyomkodással, alatta bekarcolt vonallal díszített, gömbölyü testü fazékból származik (13.10/6.1.1). Két állatcsont is volt az objektum betöltésében.

\section{9. gödör}

A szelvény déli részén, a fekete „mocsári” talajban, az elöző objektumoktól nagyjából 50 méterre északra volt.

Ovális alakú, közepes méretű, sekély gödör, $175 \mathrm{~cm}$ átmérőjü, $20 \mathrm{~cm}$ mély, fala rézsűs, az alja ívelt volt. Betöltése sötétbarna, erősen paticsos, homokos, faszenes, a körülötte lévő „mocsári” altalajtól csak nehezen elkülöníthető. (10. tábla)

Leletanyag: közepes mennyiségü kerámiatöredék (13.10/19.1.1-12.). A leletanyag legszebb részét egy csillámos és apró kavicsos homokkal soványított, sárgásvörös, helyenként kormos felületű cserépbogrács perem- és oldaltöredékei jelentik. A pereme kifelé vastagszik, csúcsán álló háromszög átmetszetü, teteje vízszintes. Az egyik töredéknél épen megmaradt a felfüggesztésre szolgáló két lyukkal ellátott rész, a szemben lévő oldalán csak az egyik átfúrt lyuk látszódik. A lyuknál a perem ivelten megvastagszik. (13.10/19.1.1.). Az objektumban több fazéktöredék is volt. Kiemelhetünk közülük egy homokkal soványított, szürkésbarna színű, háromszög átmetszetű, fedő számára 
kissé profilált peremet, amelynek a szájánál, a perem legfelső részén egy bekarcolt csík fut körbe (13.10/19.1.2.) valamint egy csillámos homokkal soványított, enyhén kihajló, enyhén megvastagodó, egyenesen levágott peremtöredéket (13.10/19.1.3.). $\mathrm{Az}$ oldaltöredékek között a díszítetlenek mellett van rádlidíszes (13.10/19.1.4.), csigavonal-díszes (13.10/19.1.6-8.), hullámvonal-díszes (13.10/19.1.9.) és bekarcolt egyenes vonalakkal bordázott töredék (13.10/19.1.10.) is.

Egy, a kinézete alapján őskori orsókarikát is találtunk (13.10/19.2.). Emellett több bekeveredett késő bronzkori töredék, 4 apró darab lemezszerü vastöredék (13.10/19.1.21.), 4 kődarab, közte egy megmunkált, szürke színü, lapos kőtöredék (13.10/19.1.20.) és kevés állatcsont volt az objektumban.

\section{2. gödör}

A 67/5. lelöhely középső részén, a 19. objektumtól majdnem 100 m-re északra volt, római objektumot metszett. Egy része a keleti szelvényfal alá esett, kilógott a szelvényböl.

Ovális alakú gödör, fala rézsűs, az alja ívelt volt. Közepes nagyságú, viszonylag sekély mélységủ $-170 \mathrm{~cm}$ hosszú, 40 $\mathrm{cm}$ mély - objektum volt. Betöltése világosbarna, paticsos, faszenes humuszos-löszös. (10. tábla)

Leletanyaga kb. félkosárnyi állatcsont (állkapocs ill. szarv is), több kő és paticsdarab, 2 megmunkált kőtöredék, kevés római töredék mellett (13.10/22.1.6-11.) kevés Árpád-kori töredék (13.10/22.1.1-5.). Utóbbiak közé két díszítetlen (13.10/22.1.4-5.), egy rádlidiszes (13.10/22.1.2.) és egy csigavonalas (13.10/22.1.3.) fazék-oldaltöredék mellett egy csillámos homokkal és apró kaviccsal soványított, kormos, szürkésbarna törésfelületű fazék kiszélesedő, felfelé húzott, fedő számára profilált peremü töredéke tartozott. Az edény nyaka és az ívelt válltöredék találkozásánál körbefutó, rádlidíszes minta volt (13.10/22.1.1.).

\section{0. gödör}

A $67 / 5$. lelöhely északi részén, a 22. gödörtöl nagyjából 40 m-re volt, a 242., 282. római árkot vágta.

Szabálytalan kör alakú, rézsűs falú, ívelt aljú objektum. 150 $\mathrm{cm}$ átmérőjü, $30 \mathrm{~cm}$ mély. Betöltése barna humuszos homok. (10. tábla)

Leletanyagában római és őskori kerámia (13.10/230.1.3-4) mellett két Árpád-kori kerámia (13.10/230.1.3-4) - egy rádlimintás cserépbogrács oldaltöredéke (13.10/230.1.1.-7. tábla) és egy díszítetlen aljtöredék (13.10/230.1.2.) volt.

\section{7. kemence}

A 67/5. lelöhely északi végében volt. Beleásták a 346 . nagyméretű római objektumba. Az előző Árpád-kori objektumtól nagyjából 130 m-re van, ez nyitja a dombtetőn lévő objektumok sorát, innentől az objektumok sürün követik egymást.

A külső kemence kelet-nyugati tájolású, az előtérgödre keleten, a kemencéje nyugaton volt. A kemenceplatni a nyesett felszíntöl $25 \mathrm{~cm}$-re volt (magasabban szedettük a géppel itt). $150 \mathrm{~cm}$ átmérőjü, a közepe felé mélyült kissé. A szája keleten volt. A platni igen vastagon átégett, egy $3-5 \mathrm{~cm}$ vastag szürkésbarna réteg alatt kb. $3 \mathrm{~cm}$ vastag vörösre égett réteg volt, ami a kemence szájánál és középső részén volt vastagabb, a nyugati részén vékonyabb. A platni alatt nem volt kerámiaréteg. Az előtérgödör eredetileg nagyjából szív alakú lehetett, kissé a déli részén túl lett bontva, $205 \mathrm{~cm}$ hosszú, $60 \mathrm{~cm}$-re mélyült a nyesett felszíntől. Az előtérgödör fala kissé ivelten szükül, az alja ívelten lejtett a kemence felé. Betöltése a platni felett erősen paticsos, az előtérgödör erősen paticsos-faszenes sötétbarna humuszos volt. Az előtérgödör lemélyedő részénél paticsos sáv futott. (10. tábla)

Leletanyaga: platni alatt csak elszórtan volt kerámia, több római kerámia (13.10/347.1.3-12.) mellett, egy díszítetlen és egy rádlidíszes oldaltöredék (13.10/347.1.1-2.).
A platni feletti részből csillámos homokkal és kaviccsal soványított, barnás színű fazék töredéke került elő. A nyak és váll találkozásánál bekarcolt vonallal, alatta csigavonalszerüen körbefutó rádlimintával díszített, a nyakán átfúrt lyuk volt (13.10/347.3.5.). Csigavonalas oldaltöredék (13.10/347.3.7.) és egy aljtöredék (13.10/347.3.6.) is volt itt, római és őskori kerámia mellett (13.10/347.3.8-15.).

Az elötérgödörből egy csillámos homokkal soványított, világosbarna, kormos felületű, háromszög átmetszetű, belső felén fedő számára profilált peremtöredék került elő (13.10/347.2.1.). Ezen kívül, díszítetlen aljtöredékeket (13.10/347.2.2-3 .,13.10/347.2.10.), díszítetlen (3.10/347.2.8-9, 13.10/347.3.4.) és csigavonalas díszű (13.10/347.2.6-7.9., 13.10/347.3.1-3.) oldaltöredéket, több római kerámiát $(13.10 / 347.2 .11-14$.$) és$ kevés állatcsontot is találtunk.

\section{2. gödör}

A 67/5. lelőhely északi részén, a 347. kemencétől 20 m-re északra volt.

Kör alakú, kisméretű, sekély gödör, $(120 \mathrm{~cm}$ átmérőjű, $20 \mathrm{~cm}$ mély) fala rézsűs, az alja ívelt volt. Betöltése szürkésbarna humuszos, paticsdarabokkal, faszénnel, hamuval kevert. (11. tábla)

Betöltésében római és Árpád-kori kerámiatöredékek (13.10/572.1.1-3.) voltak. Az utóbbiak közül egy csillámos és apró kavicsos homokkal soványított, kormos, barnásfekete felületű, kissé felhúzott, fedő számára profilált peremű, nagyméretü, csigavonalas-díszü fazék töredékeit kell kiemeln (13.10./572.1.1.). (7. tábla) Római téglatöredék és egy lapos, megmunkált, eredetileg téglatest alakú kőtöredék is volt az anyagában (13.10/572.4.).

\section{6. gödör}

A 67/5. lelöhely északkeleti részén, az 572. objektumtól 27 m-re volt.

Kör alakú, közepes méretű, mély gödör. Fala méhkasszerủen kissé kifelé tart, az alja vízszintes. Az átmérője a szájánál $125 \mathrm{~cm}$, az alján $145 \mathrm{~cm}, 150 \mathrm{~cm}$ mély. Betöltése sötétbarna löszös humusz, paticcsal kevert, föleg a felső részén, alatta sárgásabb, löszösebb réteg, az alján faszénréteg volt. (11. tábla)

Leletanyaga: kevés kerámiatöredék, ezek nagyobb része római volt (13.10/656.1.3-9.), de Árpád-kori kerámiát is találtunk benne. Egy csillámos homokkal soványított, világosbarna színü, kissé kormos felületü, vékonyan bekarcolt csigavonaldíszes fazék alj- és oldaltöredéke (13.10/656.1.2.) valamint egy hasonló anyagú és színű, szélesen kihajló, fedő számára profilált peremủ, vállán körömbenyomkodással díszített, nagyméretű fazék töredéke (13.10/656.1.1.) volt ebböl korszakból való. Egy téglatöredék (13.10/656.1.13.) mellett több megmunkált kő is volt benne (13.10/656.1.10-12); egy fenőkő-darab (13.10/656.1.11.) talán Árpád-kori, egy - talán gúla alakú nehezékből származó kődarab (13.10/656.1.10.) inkább római lehet.

A következő objektumok a 67/4. lelöhelyhez tartoztak. A két lelőhely feltárását délről és északról kezdtük meg, a két ásatás középen ért össze.

\section{1. gödör}

A 67/4. lelöhely legdélebbi Árpád-kori objektuma. Ez azt jelenti, hogy a 656 . gödörtöl néhány $m$-re keletre volt. Kisebb méretü, kerek gödör. $110 \mathrm{~cm}$ átmérőjü, $20 \mathrm{~cm}$ mély. Fala rézsüs, az alja vízszintes. Betöltése szürkésbarna kevert. (11. tábla)

Leletanyaga: egy csillámos homokkal soványított, kormos felületű, gallérszerűen felhúzott, lapos háromszög átmetszetű peremü edény töredéke. A vállán sürün bekarcolt, párhuzamosan körbefutó vonalakkal, alatta körömbenyomkodás-szerủ sorral díszített töredék (13.9/551.1.1.). Csillámos homokkal és apró kaviccsal soványított, halványvörös színü, kormos felületű fedő töredéke. A lapos, tányérszerủ fedő füle 
a peremröl a fedő belsejébe nyúlik. A vastag, ovális átmetszetü fülön bekarcolt, függöleges irányú hullámvonal díszítés van (13.9/551.2.1.). (9. tábla)

\section{4. és 625. külsö kemence és elötérgödre}

A 67/4. lelőhely déli részén, a 656. gödörtöl 13-14 m-re nyugat-északnyugatra volt.

Kelet-nyugati tengelyű külső kemence. Az elötérgödör keleten, a kemence nyugaton volt. (11. tábla)

624. kemence

A kemence $120 \mathrm{~cm}$-es platnija $25 \mathrm{~cm}$-rel a nyesett felszín alatt volt. Kissé a közepe felé mélyült, jó állapotban maradt meg, vastagon átégett. Fala $20-25 \mathrm{~cm}$ magasan megmaradt (a gép itt kevésbé szedte le). $150 \mathrm{~cm}$ átmérőjū, cipó alakú boltozata lehetett. A 624. objektum felett több római (13.9/624.1.13., 13.9/624.2.12.) és egy Árpád-kori töredék volt. Ez utóbbi egy csillámos homokkal és kaviccsal soványított, szürkésfekete, kormos felületü, szürke törésfelületű, szélesen bekarcolt, sekély csigavonallal díszített, gömbölyű fazék töredéke (13.9/624.2.3.). Hőtartó rétege nem volt

625. elötérgödör

Lekerekített sarkú téglalap alakú, $160 \mathrm{~cm}$ hosszú, a platnitól 15-20 cm-rel volt mélyebben. Keleti, kemencétől távol lévő $60 \mathrm{~cm}$-es része sekélyebb, csak kissé lejtő padkaszerü rész volt itt. Ezután fala ívelt, az alja a padkaszerü rész előtt volt a legmélyebb. A platni előtt kétoldalt ívelt aljú, $30 \mathrm{~cm}$ nagyságú, gömbölyủ lemélyedések voltak. Betöltése paticcsal és faszénnel kevert szürkésbarna humuszos. Egyszerre, felhagyás után töltődött fel a platni feletti rész és az előtérgödör.

Leletanyagát több római és őskori töredék (13.9/625.1.5-6, 13.9/625.2.11-17.) (13.9/625.2.3.1-2.) mellett Árpád-kori fazéktöredékek alkották. (9. tábla) A nagyobb része egy csillámos homokkal soványított, szürkésfekete, kormos felületű, nyakán és vállán ferdén bekarcolt vonalakkal díszített, hasán csigavonaldíszes fazékból származik (13.9/625.1.1.). Az edény pereme a belső oldalán fedő számára csak enyhén tagolt, külső oldalán gömbölyűen vastagodó. Előkerült egy csillámos homokkal és apró kaviccsal soványított, jól korongolt, téglavörös színű, belső részén felhúzott, fedő számára profilált, kívül lekerekített háromszög átmetszetű peremtöredék (13.9/625.1.3.) és egy csillámos homokkal és kaviccsal soványított, szürkésbarna, feketére kormozódott felületü, enyhén kihajló, a külső oldalán lefelé megvastagodó, ferdén levágott, ívelt perem. Az utóbbi edény peremátmérője $15,7 \mathrm{~cm}$ volt. (13.9/625.2.2.). Több díszítetlen (13.9/625.1.2., 13.9/625.2.1, 13.9/625.2.3.) és egy fenékbélyeges aljtöredék (13.9/625.2.5.9.), valamint díszítetlen oldaltöredékek (13.9/625.1.4., 13.9/625.2.6-10.) voltak még a gödör betöltésében.

\section{8. gödör}

A 625. kemencétől körülbelül 25 m-re északkeletre volt.

Szabálytalan ovális alakú, északkelet-délnyugati tengelyü, nagyméretű, közepes mélységü $-640 \mathrm{~cm}$ hosszú, $75 \mathrm{~cm}$ mély objektum volt. Az eredeti funkciója kérdéses. A fala meredeken szűkült, az alja egyenetlen, ívelt beásásokkal tagolt. Délnyugati és északkeleti végében is volt 1-1 ívelt aljú, szabálytalan ovális alakú lemélyedés. Az északnyugati fele kissé kiszélesedett, majd a végénél összeszűkült. Ez az összeszűkülő rész sekélyebb, lehet nem az objektumhoz tartozott. Kevert szürkésbarna, alul északkeleten világosabb, löszösebb betöltése volt. (11. tábla)

Leletanyaga: római (13.9/538.9.2., 13.9/538.1.4., 13.9/538. 6.1) és Árpád-kori kerámiát találtunk benne. Az utóbbiak közül ki lehet emelni egy megvastagodó, gömbölyített, háromszög átmetszetű, belül fedő számára profilált (13.9/538.7.1.) és egy csillámos homokkal és apró kaviccsal soványított, szürkésbarna, kormosra égett, lefelé megvastagodó (13.9/538.9.1.) peremtöredéket (8. tábla). Több díszítetlen alj- (13.9/538.1.1.) és oldaltöredék (13.9/538.1.3., 13.9/538.8.1.) mellett csigavonaldíszes (13.9/538.7.3-4., 13.9/538.7.7.) és rádlidíszes (13.9/538.7.5.) töredékek is voltak benne. Több bekarcolt hullámvonallal díszített töredék (13.9/538.1.2., 13.9/538.7.6.) között az egyik töredéknél a bekarcolt hullámvonal alatt az edény oldalán csigavonal látszott (13.9/538.7.2.). Egy szögletes átmetszetű, ívelt, eredetileg talán ovális kőtöredék is volt az objektum betöltésében (13.9/538.1.5.).

\section{1-612. kemence és elötérgödre}

Az 517. objektumtól 13 m-re északnyugatra volt.

Nagyjából észak-déli tengelyủ (attól kissé északnyugat felé eltérő) objektum. A 611. kemence északon volt, a 612. előtérgödör délröl csatlakozott hozzá. (11. tábla, 12. tábla 7. kép) 611. kemence

A kemence platnija a felszínhez közel, attól 5-20 cm-re volt. Fala nem maradt meg. A platni kerek, 1,5 m átméröjü. Hőtartó rétege nem volt.

\section{2. elötérgödör}

A szív alakú, a platninál kiszélesedő előtérgödör a platnitól délre volt. $265 \mathrm{~cm}$ hosszú, a nyesett felszíntöl $40 \mathrm{~cm}$-re mélyült, a platninál $25 \mathrm{~cm}$-rel van mélyebben. A fala rézsűs, az alja kissé lejtett északra, a platni felé. A keleti részén, a platni két oldalán ívelt, $45-50 \mathrm{~cm}$-es lemélyedések voltak. Délen sekélyebb, nagyjából vízszintes, padkaszerủ része volt.

Az elötérgödörben egy csillámos homokkal és kaviccsal soványított, szürkésfekete, kormos, eredetileg vörös színü, egyenes aljú fazék töredékei (13.9/612.1.1.) adták a leletanyag nagyobb részét. Több csigavonal-díszes töredéket találtunk (13.9/612.1.2-3. 13.9/612.1.7-8.), az egyik át van fúrva (13.9/612.1.8.), a lyuk elhelyezkedése alapján nem valószínü, hogy orsókarika készült volna, inkább javítás nyoma lehet. Egy hullámvonalköteg-díszes válltöredék (13.9/612.1.6.) és két peremtöredék is volt az objektum betöltésében. Az egyik csillámos homokkal és kaviccsal soványított, szürkésfekete, kormos felületű, a külső oldalán háromszög átmetszetűen megvastagodó peremtöredék (13.9/612.1.4.). A másik perem csillámos homokkal és kaviccsal soványított, szürkésbarna színű, kifelé vastagodó, lekerekített háromszög átmetszetü, vastag peremü töredék (13.9/612.1.5.). Római töredékek (13.9/612.1.9-10.) és több állatcsont is volt az objektum anyagában.

\section{5-438 kemencebokor}

Ez a háromkemencés kemencebokor a legészakibb objektum. A többi hasonló korútól külön, a 612. objektumtól 67 m-re északra volt. Ráásták a 439. késő bronzkori gödörre.

A 437. számú előtérgödörhöz északról a 435., keletröl a 436., délkeletről a 438. kemence csatlakozik. (11. tábla) 437. előtérgödör

Az előtérgödör185×200 méter átméröjü. Ovális alakú volt, a fala meredeken szükült, az alja ívelt volt. Betöltése szürkésbarna, kevert paticsos humuszos volt.

$\mathrm{Az}$ előtérgödörben több őskori, avar és római kerámiatöredék (13.9/437.4.1-2., 13.9/437.2.3-5.) mellett középkori töredékek voltak. Két aljtöredéket találtunk, az egyik fazékból (13.9/437.2.2.), a másik pohárból (13.9/437.2.1.) származik. Egy csillámos homokkal és apró kaviccsal soványított, barna, kormos felületü, enyhén kihajló, ferdén levágott peremü, vállán bekarcolt hullámvonaldíszes fazék töredékeit találtuk még az objektum betöltésében (13.9/437.3.1.). 435. kemence

A platni a 439. objektumon feküdt. $130 \mathrm{~cm}$ átmérőjű, kerek kemence volt. Mivel a nyesett felszínen volt, a fala, boltozata nem maradt meg.

A platni felett öskori töredékek mellett (13.9/435.4.5-12.), csigavonaldíszes (13.9/435.1.1., 13.9/435.1.3.,13.9/435.6.1.), rádlidíszes (13.9/435.4.1., 13.9/435.5.1., 13.9/435.6.2.) és díszítetlen (13.9/435.1.2.) oldaltöredékek voltak a betöltésben. $A$ 
platni alatt több késő bronzkori töredék (13.9/435.3.1-7.) is volt - ez azzal is magyarázható, hogy az objektumot egy őskori gödörre ásták rá. Emellett több Árpád-kori kerámiát is találtunk. Egy csillámos homokkal és apró kaviccsal soványított, szürkésbarna, kormosra égett, kihajló, egyenesen levágott peremü fazék számos töredéke mellett (13.9/435.3.2.) egy fazék alakú bogrács vagy bográcsfazék töredéke volt a platni alatti részben. A csillámos homokkal és kaviccsal soványított, szürkésbarnára, kormosra égett felületű edénynek kissé vastagodó, ferdén levágott és kissé gömbölyített pereme van. A perem alatt néhány centiméterrel, a belső részén alakították ki a felfüggesztésére szolgáló fülét (13.9/435.3.1.). Számos töredékét találtuk egy homokkal és apró kaviccsal soványított, szürkésbarna, kormosra égett, enyhén kihajó, ferdén levágott, kissé megvastagodó peremü, egyenes aljú csigavonaldíszes fazéknak. A perem átméröje $16 \mathrm{~cm}$ volt (13.9/435.4.4.).

436. kemence

A kemence platnija $130 \mathrm{~cm}$ átmérőjü, kerek, nagyjából egyenes. A nyesett felszínhez közel, nagyjából attól $10 \mathrm{~cm}$-re volt, a fala csak néhány $\mathrm{cm}$-en volt követhető. A platni előtérgödör felé eső része hiányosan maradt meg, részben megsemmisült. Hőtartó rétege nem volt, felette egy római kerámia volt (13.9/436.2.1.).

438. kemence

A kemence közvetlenül nem kapcsolódik az elötérgödörhöz, ennek az oka, hogy a nyesett felszínen volt és egy részét a gép is elvitte. A falából semmi nem maradt, a platni is hiányosan maradt meg. Utóbbi kerek alakú, nagyjából $150 \mathrm{~cm}$ átmérőjü lehetett, enyhén homorú az alja. A platni alatt ritkásan volt kirakva kerámiával. Római és őskori (13.9/438.1.13.) töredékek is voltak az anyagában. Emellett díszítetlen (13.9/438.1.11-12.), rádlidíszes (13.9/438.1.7-8, 13.9/438.1.10.) és csigavonalas (13.9/438.1.9.) oldaltöredékek, aljtöredékek (13.9/438.1.5-6.) és peremtöredékek fordultak elö. A peremek között volt gömbölyített (13.9/438.1.1.) és ferdén levágott (13.9/438.1.2.) is. Egy csillámos homokkal és kaviccsal soványított, eredetileg vörösesbarna, kormos felületü, szürke törésfelületü, belső felén fedő számára felhúzott, ferdén levágott, gömbölyített, külső oldalán megvastagodó, háromszög átmetszetủ peremtöredékek (13.9/438.1.3-4.) emelhetőek még ki az anyagából.

\section{Az objektumok}

\section{Épület}

Egy meneteles bejáratú épületet találtunk. $A$ bejárat a rövid oldalon volt, a kemencét a bejárat elé helyezték el. Hasonló szerkezetű házak nyomát számos helyről ismerjük. ${ }^{19}$ Hazánk területén - elsősorban a Duna-kanyar környékén, valamint az Észak-Dunántúlon és a Kisalföldön - már a kora Árpád-kortól megjelentek a rövid oldali, elsősorban meneteles bejárattal és általában a bejárat mellett elhelyezkedő, leginkább négyszögletes kőkemencével rendelkező házak. Később az ország más tájegységein is elterjedtek az ilyen épületek, ${ }^{20}$ a 12. századtól az északkeleti térségben és az Alföldön is kimutathatóak. ${ }^{21}$ Ahogy az alföldi Tiszafüred-Majoroson, ${ }^{22}$ úgy az általunk feltárt házban is agyagkemence volt a

19 A teljesség igénye nélkül például Pilismarót-Szobi révnél (Kemenczei-Stanczik 1979, 7-15.), Kéménden (Nevizánszky 1982,

75.), Visegrád-Várkertben (Kovalovszki 2002, 86., 17. kép), MuzslaCsenkén (Kuzma-Oždani-Hanuliak 1983, 143., 337., 87/1. kép), Tatabányán (Vékony 1980, 28-29.), Hejökeresztúron (Wolf 1997.139.) figyeltek meg ilyen helyzetü, általában kőkemencés házakat.

20 Balassa 1985, 64; Fodor 1989, 23-25., Takács 2002. 32-33.

21 Balassa 1989. 68-69., Fodor 1989, 23-25.

22 Fodor 1989, 23-25. bejárat mellett. Elmondhatjuk, hogy a rövid oldali, meneteles lejáratú házak fontos Somogy megyei példáját találtuk meg. Szerkezete inkább a korábbi időszakra teszi az épületet, a leletanyaga is ezt támasztja alá.

A lelőhely északi részén számos kemence volt, de itt már újabb épületet nem találtunk, ez a talajnak a dombtetőn való erős lepusztultságával is magyarázható.

\section{Külső kemencék}

A korszak falvainak egyik jellemzője a szabadtéri kemence, ezekből többet is találtunk. 3 esetben az előtérgödörhöz egy $(347,624,611)$, egyszer két $(5,7)$, egyszer pedig három kemence tartozott $(435,436,438)$. A kemencék ahhoz az általánosnak tekinthető típushoz tartoznak, amelyet elöször Méri István mutatott be. ${ }^{23}$ A kovásztalan lepénykenyér sütésére szolgáló kemencéket a megásott előtérgödörből a földbe vájták. A lelöhelyünkön talált kemencéknél az előtérgödör 25-50 $\mathrm{cm}$-rel volt mélyebben a platni szintjénél, a tengelyük a platni felé mutatott.

Az elötérgödrök közül a 347. és 612. előtérgödör szív alakú, szélességük a platni előtt a legnagyobb, (205 illetve $265 \mathrm{~cm}$ nagyságú), a 625. lekerekítet sarkú téglalap alakú (160 cm-es). A két- és a háromkemencés gödröket szabálytalan oválisnak nevezhetjük. A kemencéket külön időszakban használhatták, a gödrüket is bővíthették, alakíthatták, a gödrük viszonylagos szabálytalansága is erre utalhat. A 16. előtérgödör nagyméretű $360 \mathrm{~cm}$-es nagysága, egymással szemben a két rövid oldalon lévő kemencéje arra utalhat, hogy a második fázisban jelentősen növelhették a gödör méretét, a 437. gödör 200 cm-es nagysága nagyjából megfelelne az egy kemencés előtérgödrök méretének. A 347., 625. és 612. előtérgödrök enyhén a platnihoz lejtenek, bár az utóbbi másik oldalán is van egy lemélyedés. A 625. és 612 . gödrökben a platni felé eső oldal két ovális, ívelt lemélyedés van. Ezt a jelenséget már az első hasonló objektumokat közlő Méri István is megfigyelte, erősen faszenes, hamus betöltést talált bennük. Megállapította, hogy a kemencéböl ezekbe húzták a pernyét, a parázs őrzésére is használhatták ezeket. ${ }^{24}$ A kemencék fölött biztosan volt valamilyen könynyű tető, az ezt tartó cölöpök nyomát nem sikerült megtalálnunk, erre a dombtetőn az erős lepusztultság, a déli részen a mocsári talaj miatt nem is volt sok esélyünk.

A platnik szokásosnak mondható méretüek, 130160 cm-esek. Az 5., 7. és 435. sürün, a 347, 438. kemence valamivel ritkábban volt kirakva kerámiával. Több kiegészíthető edény is volt ezek között, de kisebb darabok, sőt, római és bronzkori töredékek, illetve az 5 . kemencénél egy kő is volt a hőtartó rétegben. A 436., $624 ., 611$. kemence alatt nem volt hőtartó réteg. A platnik felett több esetben megfigyelhető a boltozat beomlott, esetleg még részben álló maradványa, máskor viszont a kupola teljesen megsemmisült, maradványainak nincs nyoma. Az objektumok betöltését vizsgálva úgy tűnik, hogy ezeknél a kemencéknél a sütőfelület feletti rész az elötérgödörrel egy időben töltődött fel, a boltozat maradványait még ezelőtt eltakaríthatták.

23 Méri 1952. 60., Méri 1963.

24 Méri 1963. 274-276. 
Az 5., 7., 435., 436., 624. kemenceplatnik nagyjából egyenesek, a 347., 611. platnik kissé a kemence szája felé lejtettek. Ezt a jelenséget szintén már Méri István megfigyelte, azzal magyarázta, hogy így könnyebben kihúzhatták a lepénykenyeret a kemencékből. ${ }^{25}$

\section{Vermek}

Az objektumok közül csak egy nevezhető klasszikus tárolóveremnek, ez a dombtetőn van. Feltételezhetjük, hogy a mélyebb gödrök a település nem feltárt, magasabban fekvő részén csoportosulhattak.

\section{A leletanyag}

Mint már utaltunk rá egy intenzív római telep helyezkedik el a területen. Több objektum metsz római, esetleg őskori objektumokat, de a többiben is bőven találtunk római kerámiát - sokszor többet is mint középkorit. Sajnos a nem túl nagyszámú kő és részben a fémanyag vizsgálata is szinte lehetetlenné vált ezzel.

\section{Kerámia}

A kerámiaanyag átfogó vizsgálata nehézségekbe ütközik. A kisszámú objektum - mint látni fogjuk - viszonylag jelentős időt fog át, ráadásul a leletanyag igen egyenetlenül oszlik el. Jelentős része a 4. épületből származik, ezen kívül a kemenceplatnik - föleg az 5. és 7. alatt - volt még sok kerámia. A többi objektumban viszonylag kevés kerámiát találtunk. A leletanyagot így nem célszerü összevonva kezelni, statisztikai vizsgálatoknak alávetni.

Azt mindenképpen megállapítjuk, hogy a kerámiaanyag jó részét a fazekak alkották, míg a bográcsok csak igen kis számban fordulnak elő. Ezen kívül egy bordásnyakú edény, egy fedő és egy csésze vagy pohártöredék különíthető el.

A kerámiaanyag nagyobb része csillámos illetve apró kavicsos homokkal van soványítva, rétegesen égtek ki, törésfelületük világosszürke. Amennyiben a fazekak alakját meg lehet állapítani, többször még kissé aszimmetrikusak, zömöknek vagy közepesen zömöknek nevezhető edényekből származnak. Színük a világos sárgásbarnától a vörösesbarnán át a sötétebb szürkésbarnáig terjed. Néhány esetben már jó anyagú, jobban korongolt és égetett töredékek is előfordulnak. Ezek világosszürke színűek, kissé csillámos homokkal soványítottak.

Mindössze négy bográcsperemet találtunk, emellett egy-két nagy biztonsággal bográcsból származó oldaltöredék említhető. A bográcsok datálása nehézségekbe ütközik. Pontosabb keltezésükkel Takács Miklós foglalkozott. ${ }^{26}$ Részletesebb kronológiát a Kisalföld térségére dolgozott ki, ezért eredményei térségünkre nehezen alkalmazhatóak, különösen annak fényében, hogy a regionális különbségek egyre fontosabbnak tünnek az Árpádkori kerámiaanyag vizsgálatakor. Mégis, leginkább az általa leírtakra tudunk támaszkodni. Amennyire a kisebbnagyobb töredékekből megállapítható, a Rádon használt bográcsok a leggyakoribb típusú, pontosabb datálásra nem alkalmas edényekből származnak. A peremek

25 Méri 1963. 275.

26 Takács 1986., Takács 1993 vizsgálatakor megállapíthatjuk, hogy külön csoportba tartoznak. Míg a 4. objektumban talált szögletes, külső oldalán kissé vastagodó peremhez (13.10/4.2.2.- 1 tábla) hasonló töredékek inkább az Árpád-kor korai időszakára jellemzőek, addig a 19. objektum vízszintes, kissé lekerekített, csúcsán álló háromszög átmetszetű bográcspereméhez (13.10/19.1.1.) hasonló peremeket hosszú időn át használták, kevésbé alkalmasak a datálásra. ${ }^{27} \mathrm{~A}$ bográcstöredékeken csigavonalas vagy rádlimintás díszítést találtunk, díszítésük a fazekakéra hasonlít.

Egy bogrács-fazék peremét is megtaláltuk (13.9/ 435.3.1. - 8 tábla). Elképzelhetően több ilyen edény töredéke is lehet az anyagban. Egy átlagos oldaltöredéknél ezek nem mindig elkülöníthetőek, lévén anyagukban nem különböznek a hagyományosnak mondható edénytípusoktól. Bár a fazék alakú bográcsok, bográcsfazekak nem számítanak ritkaságnak az Árpád-kori telepfeltárásokon, de előfordulásuk általánosnak sem mondható. Ebben azonosításuk nehézsége is szerepet játszik. Feltehetően hosszabb ideig használták ezeket - Soroksár-Várhegyről a 11-12. Századra, ${ }^{28}$ a Kánai apátságból a 12. század második felére, illetve a 13. századra keltezett ${ }^{29}$ példányokat közöltek.

Egy bordás nyakú edény töredékét is megtaláltuk az 5. kemence tapasztásában (13.10/5.3.5. - 5. tábla). Az edény a 10-11. század jellemző lelete, ugyanakkor nagyjából hasonló peremü edények a 11. század után is előfordulnak. ${ }^{30}$

Egy fedőtöredéket is találtunk az 551. objektumban (13.9/551.2.1. - 9. tábla). A töredék viszonylag ritkább fedőtípusból származik. A tányérszerű fedő pereméről hajlik be a füle. A budai palota 13. századi anyagában közölték szép párhuzamát. ${ }^{31}$ Bár ott osztrák importban fordul elő hasonló, az edényt közlő Holl Imre megemlíti, hogy a cserép alakú fedő a 13. század végén, 14 . század elején a magyar fazekasok mintakincsében is megjelenik. A 13. századi cserépfedők inkább csak városokban és környékükön gyakoribbak. ${ }^{32}$ Rádon falusi környezetben, a nagyobb központoktól távolabb került elő, így valószínűbbnek tartjuk a 14. századi datálást.

Egy kisebb, világos színű pohár- esetleg csészetalp töredék is elökerült (13.9/437.2.2.). Bár formája nem rekonstruálható, ennek datálásáról is hasonlókat mondhatunk. Budán például a csészék a 13. századtól, a poharak inkább a 14. század elejétől terjednek el, ${ }^{33}$ falusi környezetben való megjelenésüket inkább ennek az időszaknak a későbbi részére valószínüsíthetjük.

Fazekak alkotják a leletanyag nagy részét. A peremek jó része kihajló, egyenesen vagy ferdén levágott, esetleg gömbölyített. Ezek a legegyszerübb, talán legkorábban jelentkező peremformák, igen hosszú ide-

27 Takács 1993. 478.

28 I. Melis 1992. 34/10, 36/5,9,10

29 H. Gyürki 1996. 22/1-3., 28/1., 29/1,6, 51/5. A kötet szerzője röviden bemutatja az edénytípust is (H. Gyürki 1996. 120-121.)

30 A kérdéssel foglalkozott Jankovich 1991. 192., Takács 1993a 216. Hasonló perem került elő a közeli Ordacsehi-Bugaszeg lelőhelyen, szintén későbbi anyagban (Nagy-Gallina-Molnár-Skriba 2001. 204.)

31 Holl 1963. 341., 372. 70/7. kép

32 A nyugati határhoz jóval közelebbi Kisalföld esetében: Takács 1993a 209.

33 Holl 1963. 339., 345 
ig élnek, pontosabb datálásra alkalmatlanok. ${ }^{34}$ Több töredék kissé vastagodik, többször a fedö számára kezdenek hornyolatot kialakítani. Ezeket a peremformákat is korán jelentkezőnek tekinthetjük, lelöhelyünkön hullámvonal-köteg díszes edényeken is előfordulnak (13.10/4.2.6. - 1. tábla). Néhány lefelé vastagodó, lekerekített háromszög átmetszetü perem a későbbi időszakra helyezhető (például 13.9/438.1.4 - 8. tábla, 13.9/625.1.3. - 9 tábla). Egy jobb anyagával is elkülönülő, felhúzott perem (13.9/551.1.1 - 9. tábla) már a 13., de még inkább a 14. századra keltezhető.

\section{Díszítés}

Az Árpád-kori kerámiák mintakincse csak korlátozottan segíti a datálást. A legkorábbi időszakra jellemző a befésült hullám- és egyenes-vonalkötegekkel való díszítés. A kutatás úgy véli ez a díszítési mód a 12. század elejére eltünhetett, ugyanakkor néhány esetben felmerült a továbbélésének lehetősége.$^{35}$ Lelőhelyünkön a 4. házban került elő nagy számban ilyen töredék. Ezen kívül csak a 612. elötérgödörben volt egy kisebb darab. Az edény felületén körbefutó egyenes vonallal, a csigavonallal díszített edények, a lelöhely minden részén előfordulnak. Ezek sokáig vannak használatban az Árpád-kor folyamán, nem alkalmasak pontosabb korhatározásra. Több edénytöredék vállát ferde, ívelt beszurkálással - úgynevezett körömbenyomkodással - díszítették. Ilyen töredékek több objektumban is előfordulnak (4., 5., 6., 7., 656.). Ezeknél az edényeknél többször megfigyelhetö, hogy a beszurkált sor alatt az edény testét csigavonallal díszítik. Ez az úgynevezett kétsoros díszítés kevésbé jellemző a 13. századtól, amit Takács Miklós a sorozatgyártás térhódításával magyaráz. ${ }^{36}$ Hullámvonal-díszes töredék a 4., 7., 19., 538., 612. objektumokban volt. Igen gyakori lelöhelyünkön az úgynevezett rádlidísz vagy fogaskerékminta vagy sarkantyúminta. A 4., 5., 7,. 16., 19., 22., 230., 347., 438., 538. objektumokban találtunk ilyen töredékeket, a minta maga nem alkalmas pontos datálásra. ${ }^{37} \mathrm{Az} 551$. objektumban talált fazéktöredéken az edény vállát sürü vonalkázással, ez alatt egy sor függőleges bevagdosással díszítették.

\section{Állatcsont}

A kevés feltárt objektumban viszonylag kevés állatcsontot találtunk - emiatt és a szuperpozíciók miatt az állatcsont statisztikai vizsgálata sem igazán lehetséges. Talán a 4. objektum csontanyaga lesz erre használható. Mindenképpen kiemelkedik a csontanyagból egy mamutfog töredéke (12. tábla 5 . kép). A 4. épület betöltésében, Árpád-kori kerámiatöredékek között találtuk. A fog sokáig vízben lehetett, ${ }^{38}$ az Árpád-kori falu lakói talán a közeli mocsaras területen találták, majd szemétbe került. Érdekes lenne tudni, hogy a vadonélő és háziasított állatok csontjait is jól ismerő középkori

\footnotetext{
34 A kérdéssel foglalkozott például Jankovich 1991. 190-191., Aradi 1998. 132., Holl 1973. 198.

35 Takács 1993. 450.

36 Takács 1993a 209-216

37 Takács 1993. 450. példákat hoz késői előfordulására.

38 Erre Dr. Ábrahám Levente hívta fel a figyelmünket, Ő erösített meg minket abban a sejtésünkben is, hogy mamutfogat találtunk - köszönet érte
}

falusi ember mivel magyarázta ezt a különös fogat.

\section{Pénzek}

A lelöhelyen nagyszámú római érme mellett egy szórványnak minősíthető Árpád-kori pénz került elő (12. tábla 1. kép). A 4. lelöhely humuszolásakor, a dombtetön lévő terület földjében, fémkeresőzés közben egy IV. Béla uralkodása alatt vert obulust találtunk. ${ }^{39}$ A pénz pontosabb datálásában V. Székely György volt segítségünkre - segítségét köszönjük. Véleménye szerint a pénzt IV. Béla uralkodási idején belül pontosabban nehéz datálni, de nagy valószínüséggel kijelenthető, hogy a tatárjárás után verték. Csak olyan éremleletekben fordult elő eddig, amelyek IV. Béla uralkodásának második felében vagy azután záródtak. A legkorábbi előfordulása a mernyei leletben volt, ennek záródása is az 1250-es, 1260 -as évekre tehető. Ez alapján is feltételezhetjük a település 13. század közepi, tatárjárás utáni létét.

\section{Fémanyag}

A fémanyag legérdekesebb része a 4. épületben talált sarkantyú (13.10/4.2.28. - 3. tábla, 12. tábla 6. kép). Ez Árpád-kori falusi feltárásokon, ha nem is túl gyakori, de egyáltalán nem szokatlan lelet, elég a Hejőkeresztúron vagy Kánán talált nagyszámú sarkantyúra gondolni. ${ }^{40} \mathrm{~A} 4$. házban talált sarkantyú a tüskés típusba tartozik. A szárakat lefelé hajló ívekbe kovácsolták, a hegye előtt gömböcskéje van, hogy a lovat kevésbé sebezze. Nagyon hasonló példány Kána falu leletei közül került elő. ${ }^{41} \mathrm{~A}$ magyarországi sarkantyúkat rendszerező Kovács László az ívelt szárakat a 12. századtól, a gömböcskék megjelenését a 12. század közepétöl indítja. ${ }^{42}$ A 4. épület viszonylag egységes és bő kerámiaanyagot tartalmazott. A nagyszámú egyenes- és hullámvonalköteg-díszes töredék alapján a feltöltődés idejét ennél kicsivel korábbra helyezhetjük. Bár nem tudjuk az épület mennyi idő alatt töltődött fel, a 12. század elejénél nem lehet sokkal fiatalabb a sarkantyú sem. Ha elfogadjuk a befésült vonalköteg-díszítés 12 . század eleji eltűnését, talán megfontolható az általunk találthoz hasonló gömböcskés sarkantyú-típusok megjelenésének idejét is korábbra helyezni egy-két évtizeddel.

Szintén a 4. objektumban talált nyílhegy is említést érdemel (13.10/4.5.3. - 3. tábla). Ilyen szakállas hegyü nyílvesszőket a Honfoglalás korától ismerünk. ${ }^{43}$ Funkciójuk többféle lehetett, halak lövésére is használhatták ezeket. ${ }^{44}$ Egy sarló pontosabb keltezésre alkalmatlan kisebb töredéke, egy vaskarika és néhány kisebb vastöredék jelenti a nagy valószínűséggel Árpád-korra datálható fémanyagot.

\section{Keltezés}

A legkorábbra a 4. épület keltezhető. A betöltésében talált számos hullámvonalköteg- és egyenes vonalkö-

39 Az Unger féle éremhatározó 247. tétele

40 Wolf 1997. 139., Terei-Horváth 2007. 166-169. - az utóbbi a szakirodalmat is összefoglalta

41 Terei-Horváth 2007. 167., 189.16/3. kép,

42 Kovács 2003. 369.

43 Kovács 2003. 311-313.

44 Szöllösy 1992. 457 
teg-díszes töredék a 11. századra, esetleg a századforduló körüli időszakra keltezi, a feltöltődése - a benne talált sarkantyú alapján is - már a 12. század elején mehetett végbe, illetve fejeződött be. A 4. épület gödre bő leletanyaggal fokozatosan töltődött fel, miközben mellette a telep még müködött.

Az 5. és 7. kemence anyagából a vonalköteg-díszek már hiányoznak. Mindkettőben előfordulnak rádlidíszes (ezt a 4. épületben alig találtunk) és csigavonalas díszü töredékek, utóbbiakat a vállon ferde körömbenyomkodással vagy hullámvonallal kombinálják. A peremek, nem vagy csak kissé megvastagodóak, fedőnek szánt hornyolat előfordul rajtuk. Az 5. platni alatt lévő bordás nyakú edény szintén korai időszakra tehető, bár régebbi kerámiát, római és őskori töredékeket is hajlamosak voltak felhasználni a hötartó rétegbe. Talán már a 12. századra tehetjük a kemencék működését. Hasonló korúak lehetnek - a hasonló kerámia alapján - a 6., 19., 22. délen lévő objektumok, de ezeknél már nehezebb a keltezés, csakúgy, mint a 230., 347. objektumoknál. A biztonsággal fiatalabbnak tekinthető objektumok a dombtetőn vannak. Az objektumok anyagának egy része már a 13. századra, sőt az 551. és 347. obijektum esetében a század végére, a 14. századra mutat.

A régészeti leletekkel a lelőhely életét a 11. századtól - de legalább a 11-12. század fordulójától - a 14. századig igazolhatjuk, az írott források alapján tovább is. Azt is megállapíthatjuk, hogy az élet nagyjából folyamatos volt, a Tatárjárás nem okozott törést a falu életében. Megállapíthatjuk, hogy a legkorábbi objektumok a mélyebben fekvő, déli területen jelentkeznek, közel a templomhoz, a legfiatalabb objektumokat a dombtetőn találjuk.

\section{Településszerkezet}

Feltételezhetjük, hogy a település széléböl sikerült egy részt feltárnunk. A legsürübb, központi részt a dombtetőre valószínüsíthetjük. A hosszú ideig élő telep néhány - nem is egyszerre müködő - objektuma alapján nehéz a település szerkezetére vonatkozóan adatokat szereznünk, ugyanakkor néhány jellegzetességre így is felhívhatjuk a figyelmet. A három legdélebbi kemencebokor (16-5-7., 347., 624-625.) tájolása hasonló, nagyjából nyugat-keleti, vagy attól kissé délnyugat felé eltérő, a következőé - a 611-612. erre merőleges. (A 345-348. kemencebokornál - háromszori megújítása miatt - nehéz az eredeti tájolását megadni.) A kemencék jól illeszkednek a legdélebbi kemencebokor mellett lévő 4. épület tengelyéhez. Feltehető az épület és az említett kemencebokor összetartozása is, a település legkorábbi rétegéhez tartozhatnak. Láthatjuk, hogy az objektumok valamilyen rendhez igazodhatnak, amelyet ráadásul hosszabb ideig tartottak is. A település földrajzi helyzete, a hosszú észak-déli irányú part ad egyfajta természetes tájolást az objektumoknak, a mai - az újkorban újjátelepült - település házai is hasonló rendben álnak. Ugyanakkor a római telep objektumai kissé eltérő, délnyugat-északkeleti irányhoz tagolt rendszerben jelentkeztek. 2012-ben újabb terepbejárást tartottunk a területen. A feltárás előtti években a terület alaposan be lett járva, de ezúttal próbáltuk kifejezetten a középkori település helyzetére információkat kapni. A területet kisebb részekre osztva, a tengerszint feletti magassághoz is igazodva próbáltuk a leleteket összegyüjteni. Természetesen a domb erős lekopása, a domboldal földjének a domb aljába való lekerülése megakadályozza, hogy a feltárással azonos pontosságú megállapításokat tegyünk. A legdélebbi, romtemplom közelében lévő - legelőként használt - terület ráadásul nem is volt bejárható. Megállapítható volt, hogy a középkori telep kiterjedése nagyjából megfelel annak, amit a feltárás eredményei is mutatnak. A későbbi időszak kerámiája a dombtetőn lévő legmagasabb részeken fordul elő, a mai település házainál, a feltárt területtöl, a mai 67-es úttól keletre sürüsödik - itt igen nagy leletsürüséggel számolhatunk. Csak ezen a legmagasabban fekvő területen találtunk - az Árpádkoriak mellett - 14-15. századi kerámiát is. Árpád-kori kerámia - a patakhoz közelebbi, mély területeken kívül elszórtan mindenhol előfordult, de a mélyebb területeken jelentősen kisebb számban. Egyértelmüen kora Árpádkorinak minősíthető kerámiát ezúttal nem találtunk.

A patak - jelenleg már részben felszántott - egykori medre jól elkülöníthető, itt semmilyen kerámia nem volt, a közelében is csak római töredékeket találtunk. A májusi friss kukoricában jól látszott az a rész is, amely egykor hosszabb időre víz alá kerülhetett - jelenleg sötét színü mocsári talaj borítja. Ezek a területek az egykori patakmederhez hasonlóan sokkal gazosabbak voltak, mint a velük egybe szántott földek. A feltárt terület déli része is ide tartozott.

A feltárás és a terepbejárások eredményei alapján feltételezhetjük, hogy a település a ma már romos templom közelében jött létre. Az itt talált viszonylag korai objektumok esetleg felvethetik a templom korai eredetét is. A későbbi időszakban, feltehetően a 13. században - talán az éghajlat és a talajvízszint változása miatt is - a mélyen fekvő területet már nem lakták, a dombtetőre húzódtak fel. A templom magasabban fekvő, szükebb környezete viszont folyamatosan lakott lehetett, ahogy ezt egy 2000-ben végzett leletmentés során részlegesen kiásott kemence 14. századra datálható kerámiája is bizonyítja. Ez is jelzi, hogy a változás nem pusztán a település délészaki irányú eltolódásában, hanem a mélyebb részekről a magasabb felé húzódásában fogható meg. Hasonló jelenséget - a település mélyebb területeinek felhagyását - figyeltek meg Balatonkeresztúr-Réti-dűlő lelőhelyen is. Mészáros Orsolya és Serlegi Gábor részben ez utóbbi lelőhely alapján vizsgálta a Balaton déli partjának középkori környezeti változásait. A jelenséget az éghajlat változásával magyarázták, azt is hangsúlyozták, hogy a térség igen érzékenyen és korán reagált ezekre. ${ }^{45} \mathrm{Az}$ általunk 2010-11-ben feltárt - egy meredek domboldalon fekvő, nagy szintkülönbségeket mutató - Lulla-Büdösalja lelőhelyen szintén hasonló jelenséget figyeltünk meg. Itt a kora Árpád-kori objektumok a mélyebben fekvő területen, a 13-14. századiak a dombtetőhöz közel sürüsödtek. 


\section{Összefoglalás}

Tanulmányunkban egy olyan középkori falu objektumait mutattuk be, amelynek - az írott források alapján - nem csak az egykori nevét ismerjük, de amelyröl viszonylag sokat is tudunk. Külön öröm, hogy korábban a te- lepüléshez tartozó templomot is feltárták. Az egykori településnek csak egy kevésbé intenzív, nem központi helyzetü részét tártuk fel, ugyanakkor ez az a terület, ahol a természeti környezet változásai a legjobban befolyásolták a település kiterjedését.

\section{Irodalom}

M. ARADI Cs. 1998: A Főnyed-gólyásfai Árpád-kori temető és település eddigi ásatásának összefoglalása. - Summary of the excavations at the Árpád-aged cemetery and settlement of Főnyed-Gólyásfa. - In: Somogyi Múzeumok Közleményei 13: 113-154

M. Aradi Cs. 2007: Somogy Megye Árpád-kori és középkori egyházszervezetének létrejötte és megszilárdulása. Doktori (Phd) diszszertáció 2007.

BALASSA M. I. 1985: A parasztház évszázadai. A magyar lakóház középkori fejlődésének vázlata. Békéscsaba 1985

BALASSA M. I. 1989: A Kárpát-medence északkeleti térsége lakóházfejlödéséröl. - Zur Entwicklung des Wohnhauses in der nordöstlichen Region des Karpatenbeckens. In: Népi építészet a Kárpát-medence északkeleti térségében. Szerk.: Cseri M. - Balassa M. I. - Viga Gy. Miskolc-Szentendre 1989, 63-84.

BENDEFY L. és NAGY I. 1969: A Balaton évszázados partvonalváltozásai. Budapest. 1969.

ÉRY I. 1967: A Látrány-rádpusztai templomrom feltárása és állagmegóvása - Freilegung und Bastandschutz der Kirchen riune von Látrány-Rádpuszta. - In: Veszprém Megyei Múzeumok Közleményei 06: 183-196.

FodoR I. 1989: Megjegyzések a középkori magyar lakóház fejlődéstörténetéhez. - Anmerkungen zur Entwicklungsgeschichte des ungarischen Wohnhauses im Mittelalter. - In: Népi építészet a Kárpát-medence északkeleti térségében. Szerk.: Cseri M. Balassa M. I. - Viga Gy. Miskolc-Szentendre 21-45.

GLASER L. 1929: Dunántúl középkori úthálózata. - In: Századok 1929. 136-167 és 257-285.

GLASER L. 1932: Középkori hadiutak a Dunántúlon. - In: Hadtörténeti Közlemények 3-4: 1-7.

H. GYüRKı K. 1996: A Buda melletti Kánai apátság feltárása. Bp.

HoLL I. 1963: Középkori cserépedények a budai várpalotából (XIII-XV. század) - Mittelalterliche keramik aus dem Burgpalast von Buda (13.-15. jahrhundert) Budapest Régiségei 20: 335-382.

HoLL I. 1973: Sopron középkori városfalai IV. - Les murs Médiévaux de L'enceinte de Sopron. Archaeologiai Értesítő 100: 180-207.

HoNTI ET AL: Honti Sz. - Fábián Sz. - Gallina Zs. - Hajdú Á. D. - Hornok P. - Soós I. - Mersdorf Zs. - Molnár I. - Németh P. G. - Polgár P. - P. Szeőke J. - Serlegi G. - Siklósi Zs. - Sipos C. - Somogy K. 2006: Régészeti kutatások az M7-es autópálya Somogy megyei szakaszán és a 67-es úton (2004-2005) Előzetes jelentés IV - Archaeological research on the Somogy county section of the M7 highway and on Route No. 67. Preliminary report IV. Somogyi Múzeumok Közleményei $17: 7-70$.

IRÁSNÉ MELIS K. 1992: Kerekegyháza középkori falu Budapest határában. - Kerekegyháza village médieval à la limite de Budapest. - In: Régészeti kutatások az M0 autópálya nyomvonalán II. Szerk.: Havassy P. - Selmeczi L. BTM Mühely 6, Budapest 1992 , 71-176.

JaNKOVICH-BÉSÁN D. 1991: Ásatások az Árpád-kori Fenék falu területén 1976-1978. - Ausgrabungen auf dem Gebiet des árpádenzeitlichen Dorfes Fenék 1976-1978. Zalai Múzeum 3 . 185-210.

Kemenczei T. és Stanczik I. 1979: Elözetes jelentés a Pilismarót-Szobi révnél 1978-ban végzett ásatásról. - Vorbericht über die im Jahre 1978 bei der Fähre von Pilismarót-Szob durchgeführten Ausgrabungen. Dunai Régészeti Híradó 1: 7-22.

KovÁcs L. 2003: Viselet, fegyverek. - In: Kristó 2003. 284-392.

KovalovszKı J. 2002: Árpád-kori házak Visegrád-Várkertben. - In: Népi építészet a Kárpát-medencében a honfoglalástól a 18. századig. - Dwelling houses from the Arpadian age in the Palace Garden in Visegrad. Szerk.: Cseri M. - Tárnoki J. Szentendre-Szolnok 2001. 81-98.

KRISTó Gy. 2003: Háborúk és hadviselés az Árpádok korában. Szukits kiadó
KRISTó GY. 2006: Magyarország története 895-1301. Osiris. Budapest. 2006

KuZMA, I., OžDANI, O. \& HANULIAK, M. 1983: Tretia sezóna výskumu v Mužle-Čenkov. Nitra 1983, 143-147.

IRÁSNÉ MELIS K. 1992: Kerekegyháza középkori falu Budapest határában. - Kerekegyháza village médieval à la limite de Budapest. - In: Régészeti kutatások az M0 autópálya nyomvonalán II. Szerk.: Havassy P. - Selmeczi L. BTM Műhely 6, Budapest 1992 71-176.

MAGYAR K. 2001: Szent István államszervezésének régészeti emlékei. Magyar Millennium 1001-2001. Segesd- Kaposvár. 2001.

MÉSzÁROS O és SERLEGI G. 2011: Környezeti változások hatása a középkori településviszonyokra a Dunántúlon. - In: Archaeologia Értesítö 136: 215-235

MÉRI I. 1952: Beszámoló a Tiszalök-rázompusztai és Túrkeve-mórici ásatások eredményeiröl I. - Otčet o raskolkah v TiszalökRázompuszta i Túrkeve-Móric. - In: Archaelogiai Értesítő 79 49-67.

MéRI I. 1964: Árpád-kori szabadban lévő kemencék - freistehende backöffen aus der regierungszeit des hauses Árpád (10.-13. JH.) - In: Archaelogiai Értesítő 90: 273-280.

Nagy Á., Gallina Zs., Molnár I. és Skriba P. 2001: Késő Árpád-kori, nagyméretű, földbemélyített építmények Ordacsehi-Bugaszegen. - Grosse, gegrabene Bauten in Ordacsehi-Bugaszeg aus de späten Arpadenzeit. - In: Népi építészet a Kárpát-medencében a honfoglalástól a 18. századig. Szerk.: Cseri M. - Tárnoki J. Szentendre-Szolnok 2001. 187-220.

NevizÁNSZKY, G. 1982: Príbytky s jazykovitým vchodovým výklenkom v Kameníne. - Meneteles bejáratú házak Kéméndről. - In: Castrum Novum 1: 67-75.

RÁCz L. 2006: A Kárpát-medence éghajlattörténete a közép- és kora-újkorban. - In: Magyar középkori gazdaság és pénztörténet. Szerk. Gyöngyössy M. Budapest. 2006.

Szalóky I. és Bódis J. 2004: A Lellei-Bozót és a Szemesi-Berek élöhelyei. - Habitats of Bozót (Balatonlelle) and Berek (Balatonszemes) (Somogy county, Hungary). - In: Somogyi Múzeumok Közleményei 16: 279-289

SzöLLősY G. 1992: Íjászati alapismeretek. - Grundkenntnisse der bogekunde. - In: A Nyíregyházi Jósa András Múzeum Évkönyve 30-32. - 1987-88. (1992) 443-476.

TAKÁCs M. 1986: Die Arpadenzeitlichen Tonkessel im Karpatenbecken. In: Varia Archaeologica Hungarica 1, Budapest.

TAKÁCS M. 1993: A kisalföldi Árpád-kori cserépbográcsok pontosabb időrendje. (Egy kísérlet a leletanyag rendszerezésére). - Die präzisere Chronologie der árpádenzeitlichen Tonkessel der Kleinen Tiefebene. (Versuch einer Systemetisierung.) - In Herman Ottó Múzeum Évkönyve 30-31/2: 447-482.

TAKÁCs M. 1993a: Árpád-kori települési objektumok Kajárpéc-Pokolfadombon. - Arpadenzritlicher siedlungsteil von KajárpécPokoldomb. - In: Communicationes Archaeologicae Hungariae 1993. 201-226

TAKÁCS M. 2002: Az Árpád-kori köznépi lakóház kutatása, különös tekintettel az 1990-es évekre. - Erforschung des Wohnhauses des gemeinen Volkes zur Arpadzeit, im Mittelpunkt die Forschung de 1990er Jahre. - In: Népi építészet a Kárpát-medencében a honfoglalástól a 18. századig. Szerk.: Cseri M. - Tárnoki J. Szentendre-Szolnok 2001. 7-54

TEREI Gy. és HoRvátH A. 2007: Az Árpád-kori Kána falu vasleletei II. - In: Budapest Régiségei XLI:153-174.

VÉKonY G. 1980: Honfoglaló őseink szállása. - In: História 3: 28-29.

Wolf M. 1997: Hejökeresztúr-Vizeköze. Árpád-kori település a XI-XIII. századból. - In: Utak a múltba. Az M3-as autópálya régészeti leletmentései. Budapest. 1997. 139. 


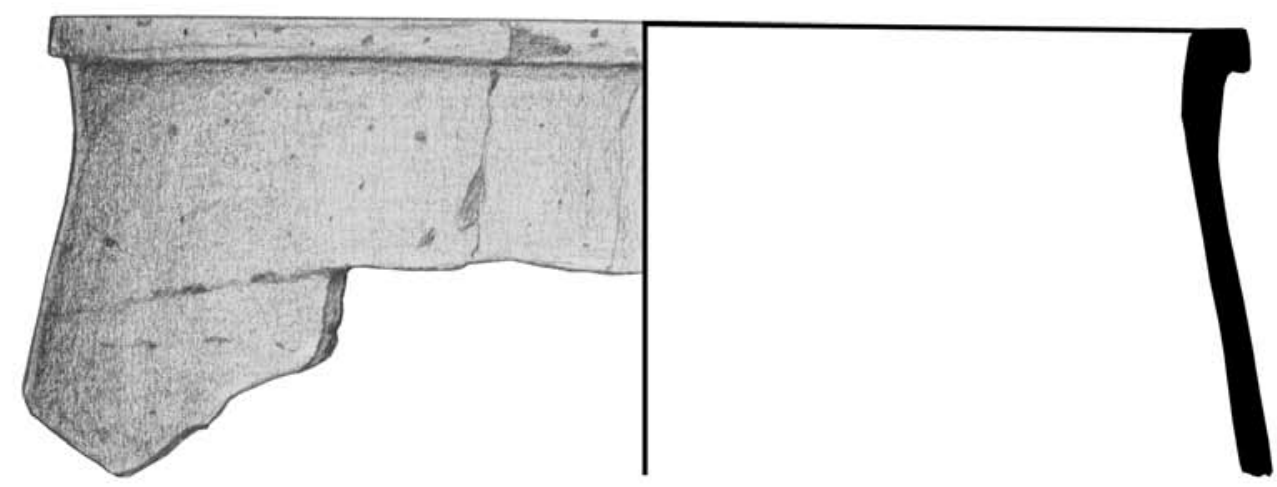

13.10/4.2.2.

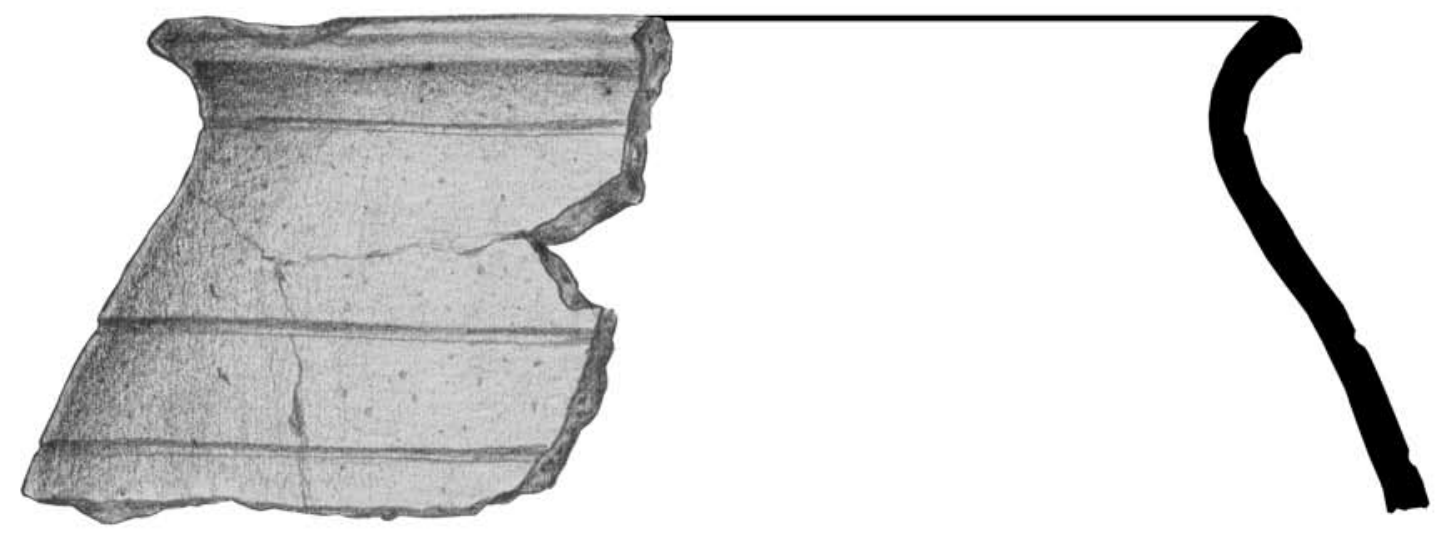

13.10/4.2.3

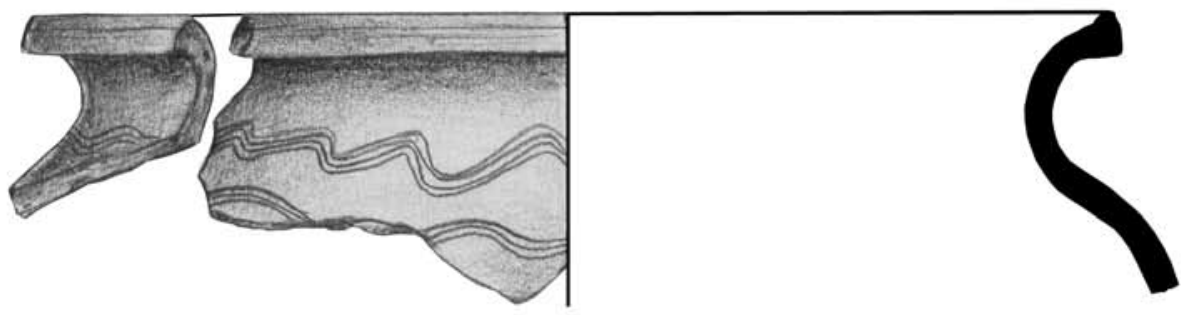

13.10/4.2.6.

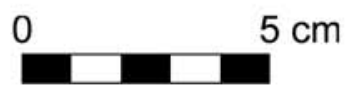




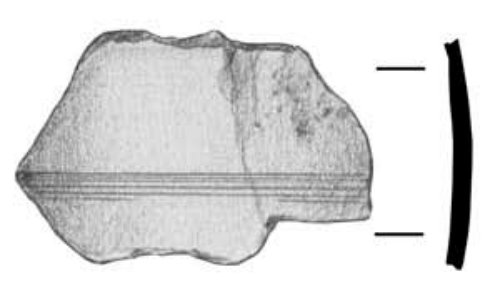

13.10/4.2.17.
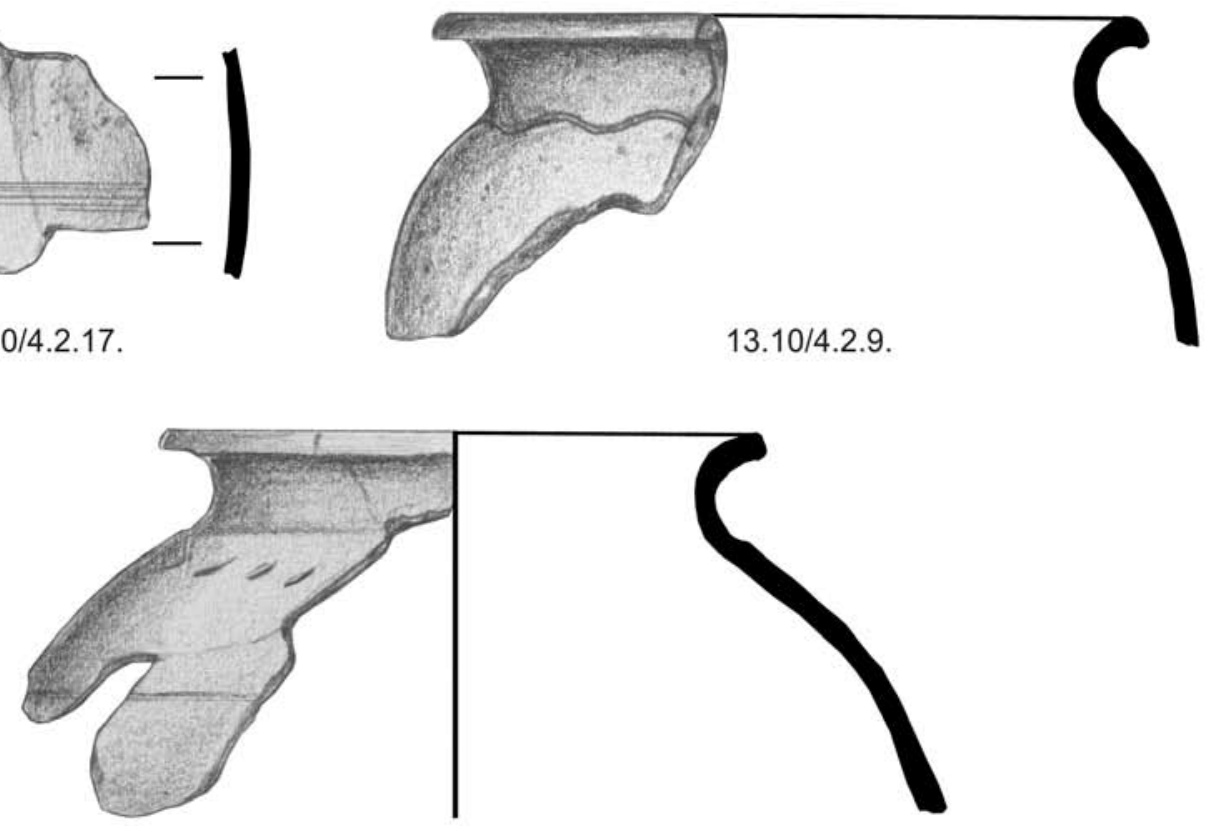

13.10/4.2.8.
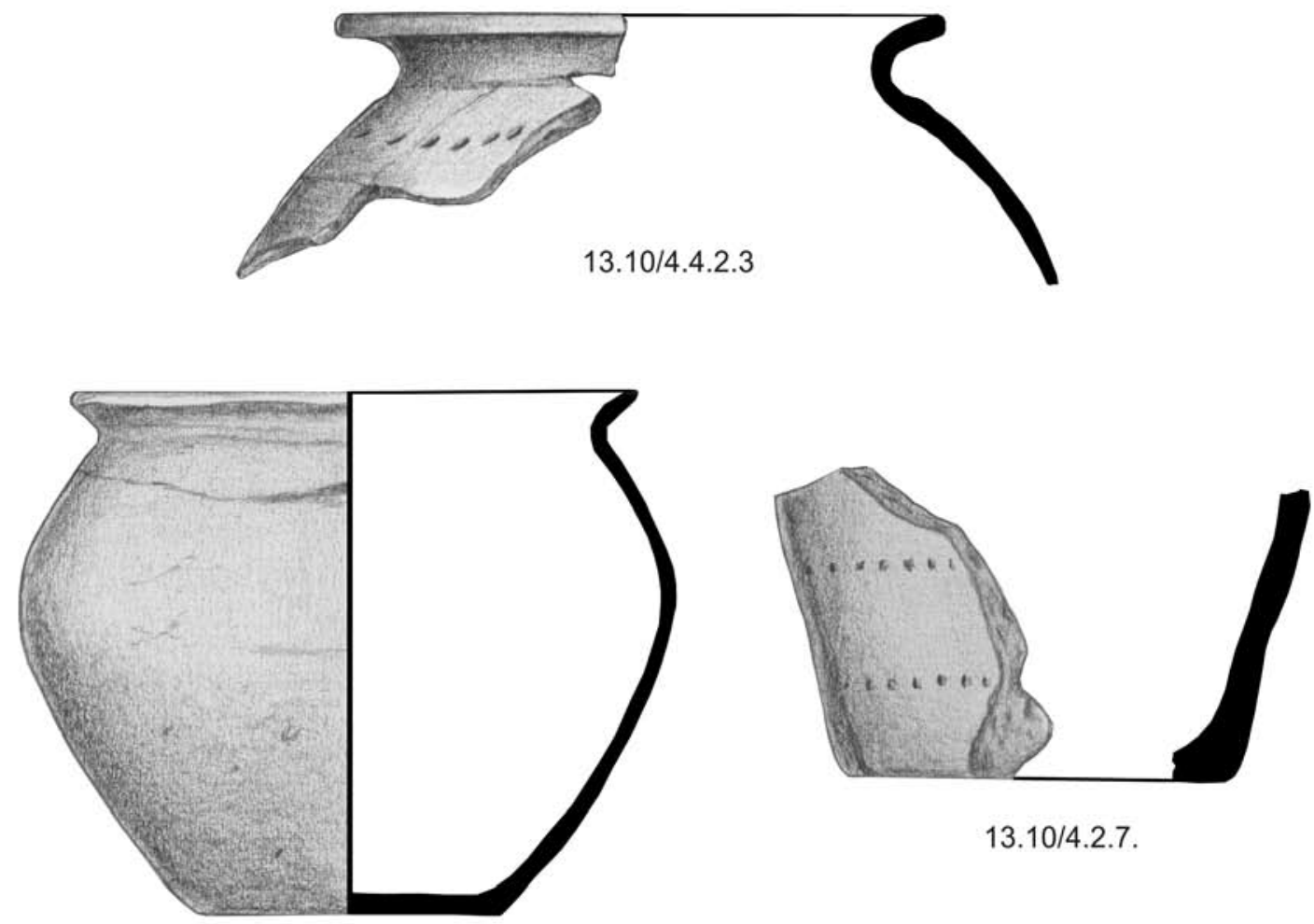

13.10/4.2.7.

13.10/4.4.1.

0

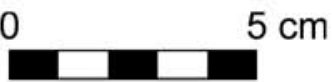

2. tábla: $67 / 5$ lelőhely, leletek a 4. objektumból 

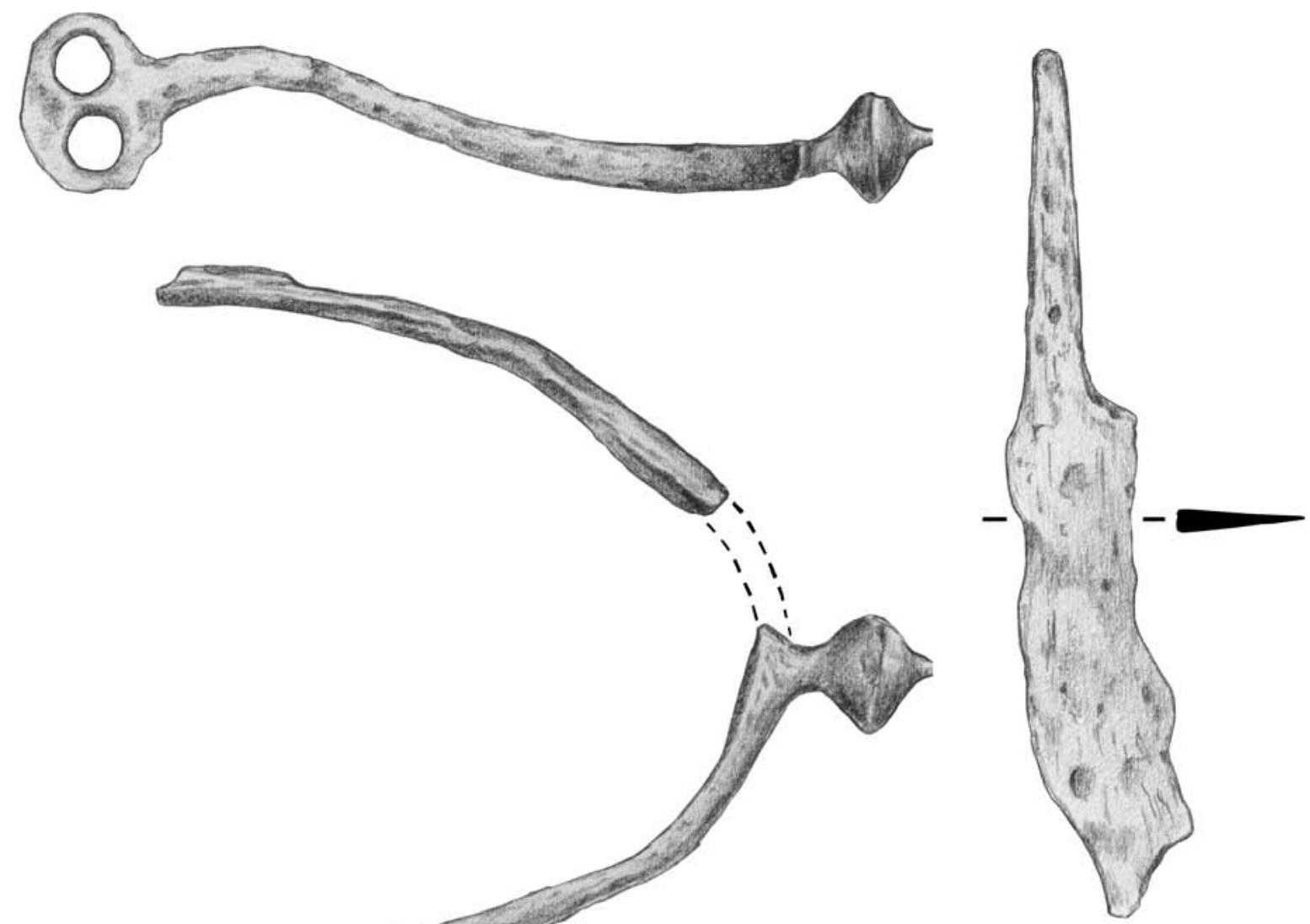

13.10/4.2.28.

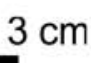

13.10/4.3.13
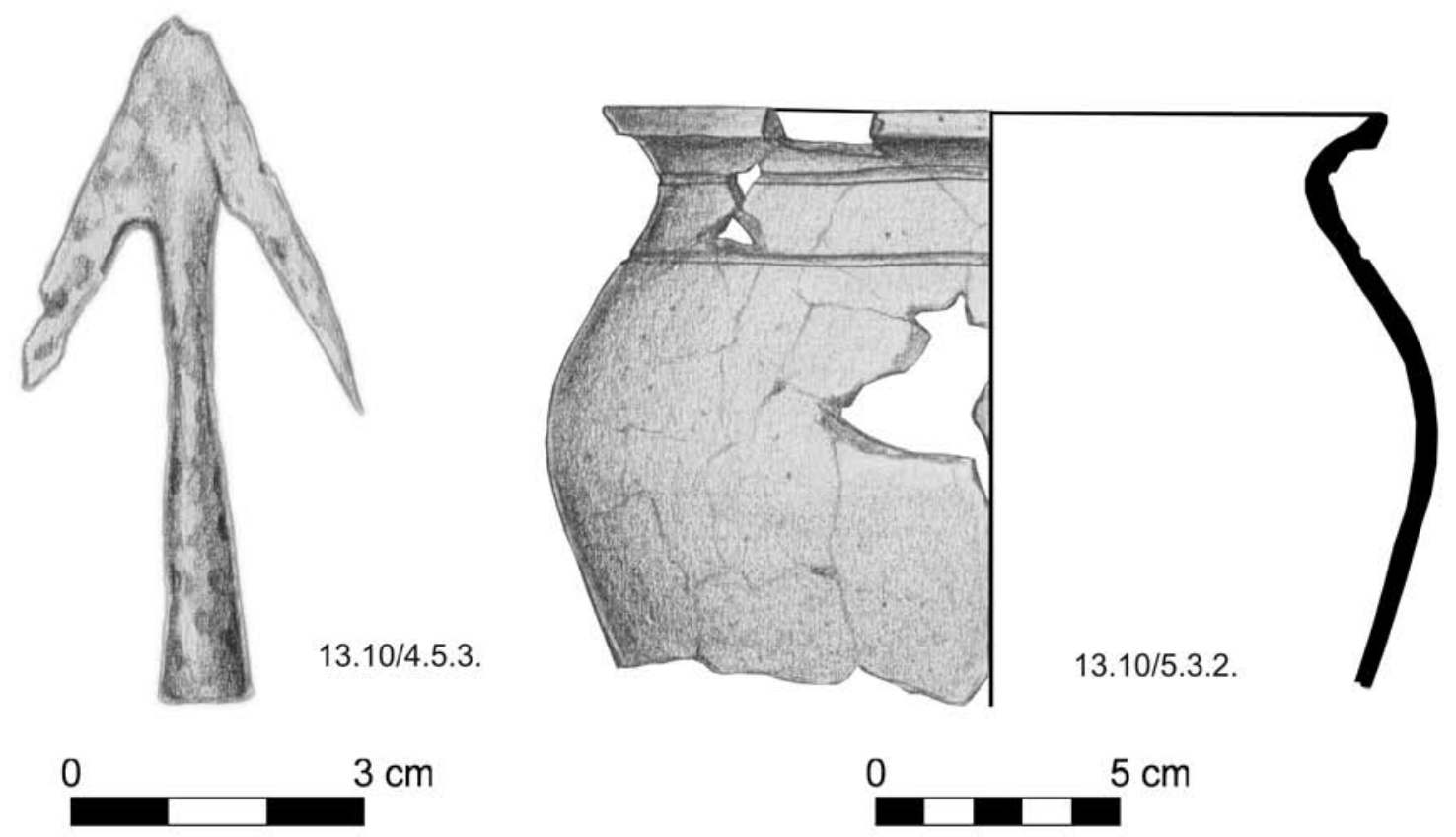

3. tábla: $67 / 5$ lelöhely, leletek a 4. és 5. objektumból 


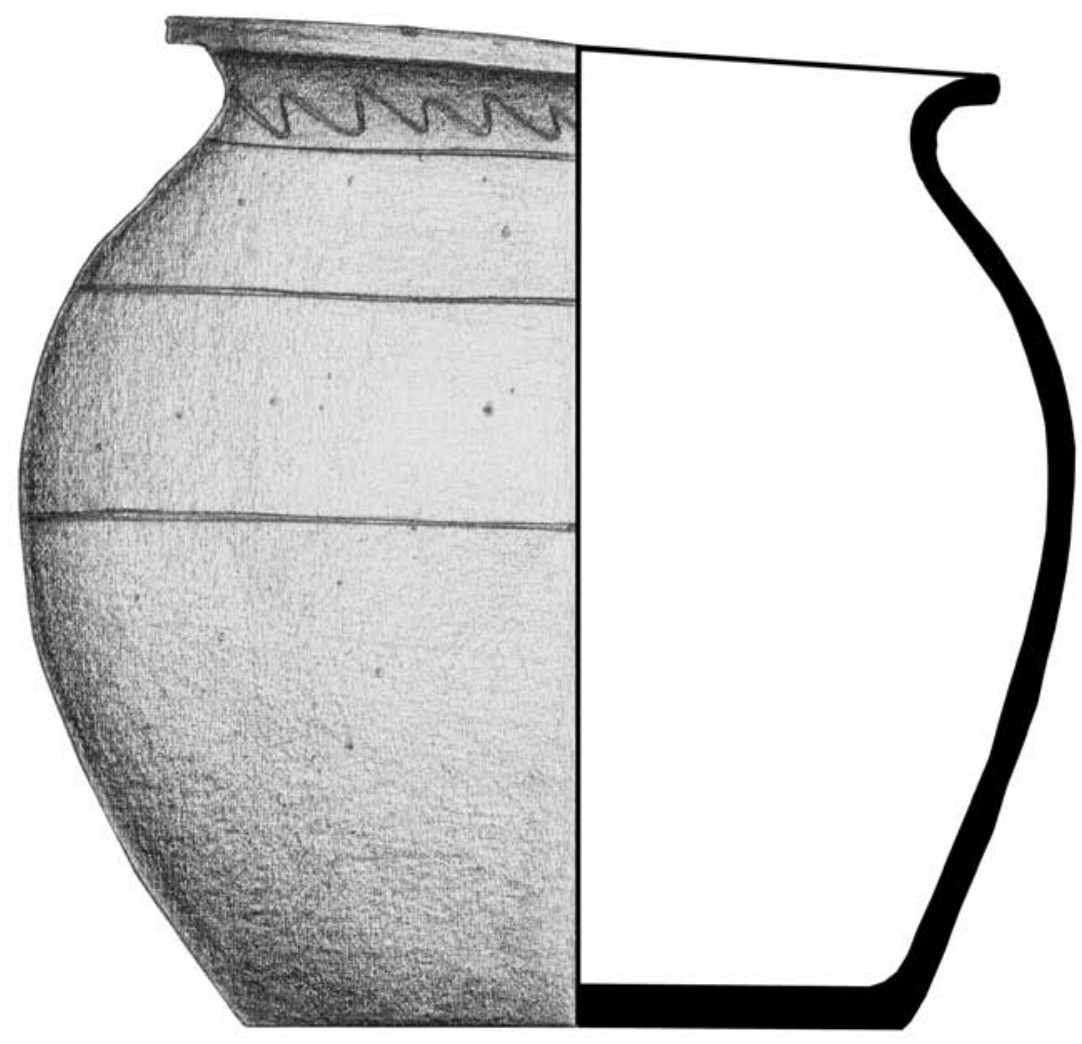

13.10/5.3.1.

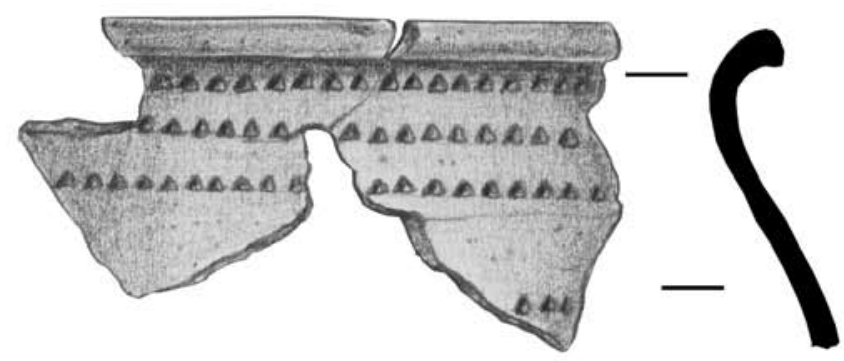

13.10/5.3.3.

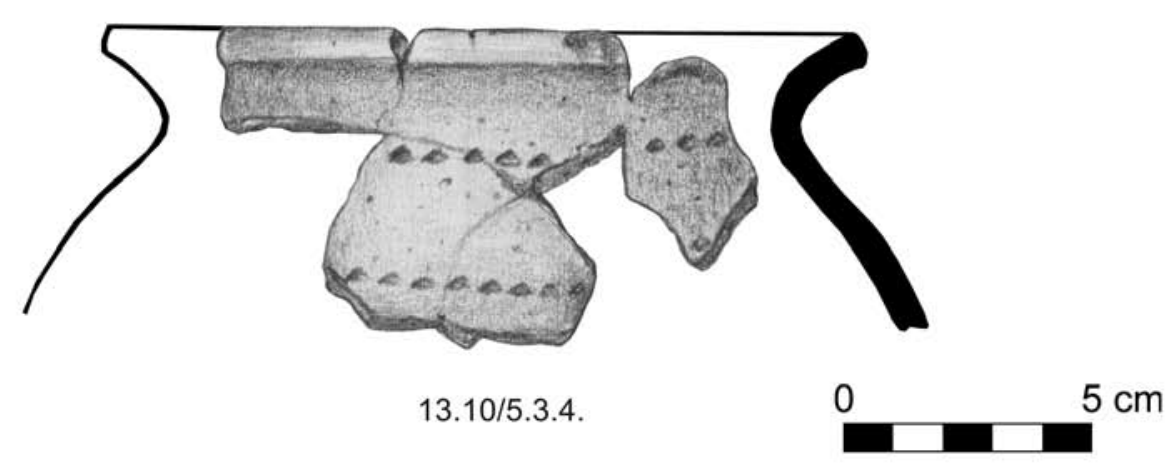

4. tábla: $67 / 5$ lelöhely, leletek az 5. objektumból 

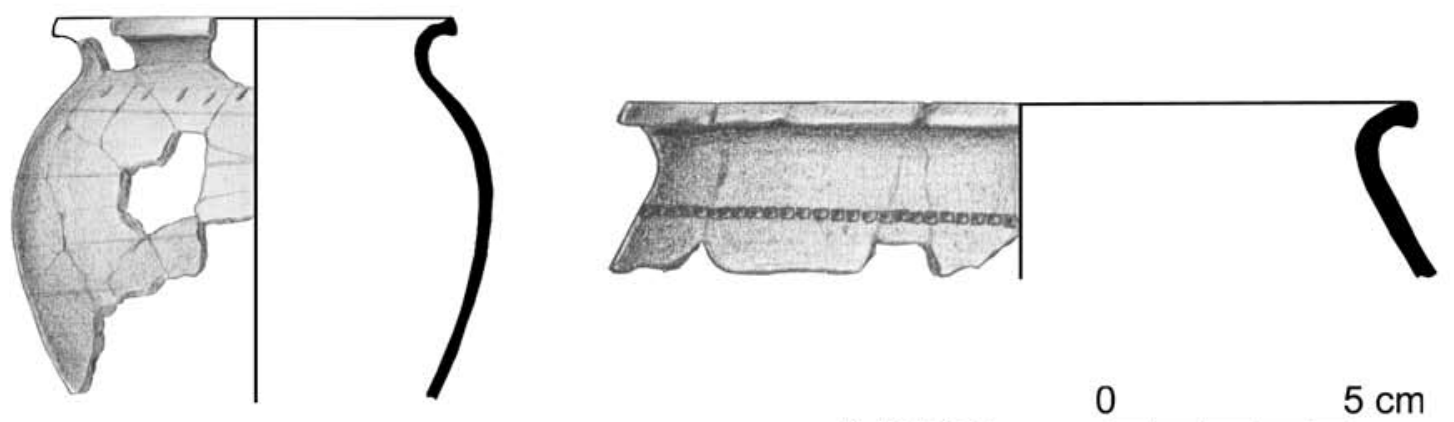

13.10/7.2.1.

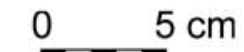

13.10/7.2.2.

$5 \mathrm{~cm}$
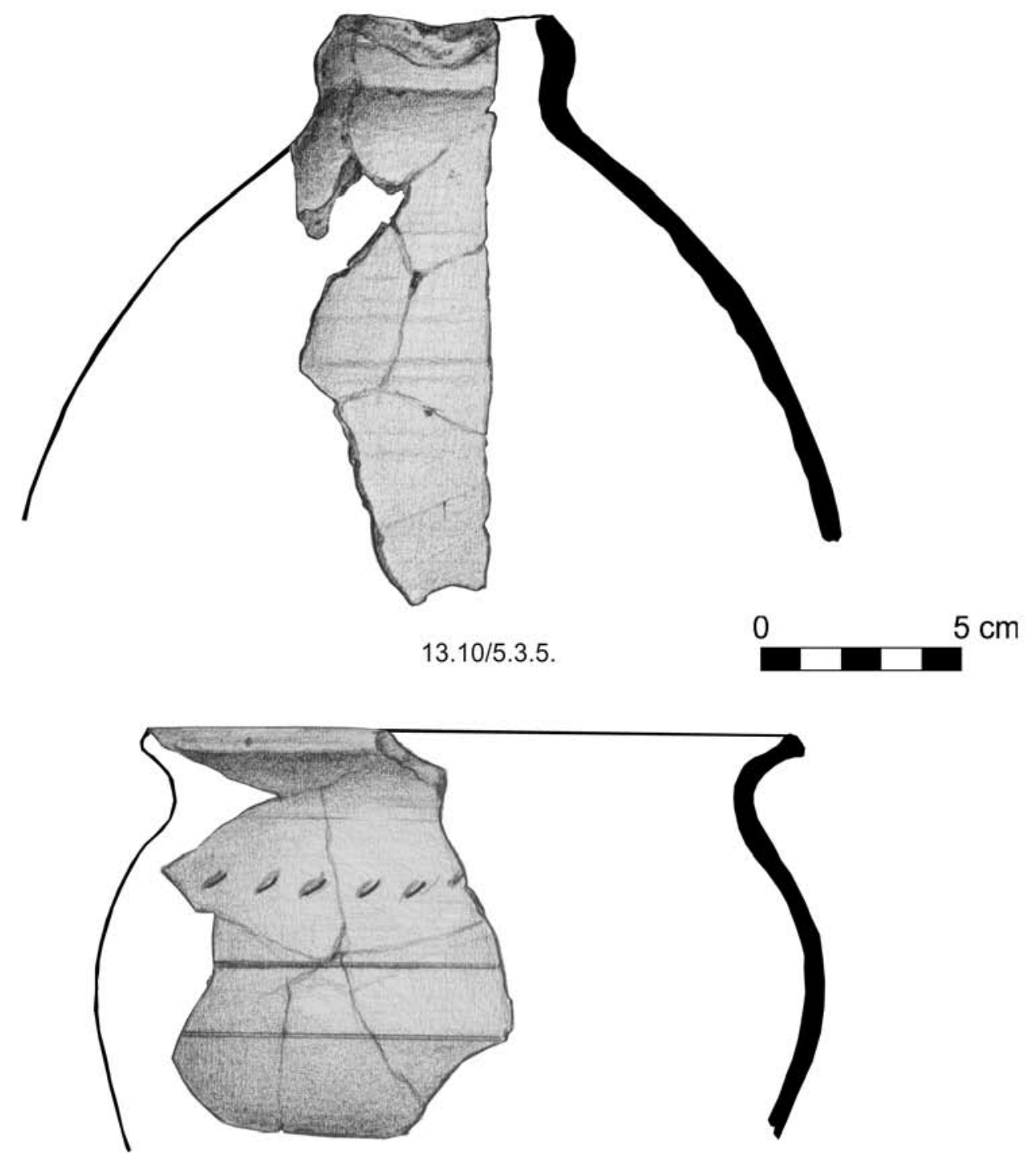

13.10/5.3.6.

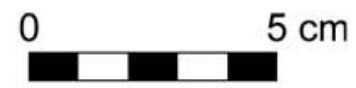

5. tábla: 67/5 lelöhely, leletek az 5. objektumból 


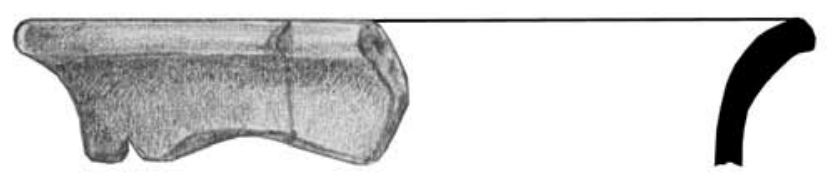

13.10/7.2.3.

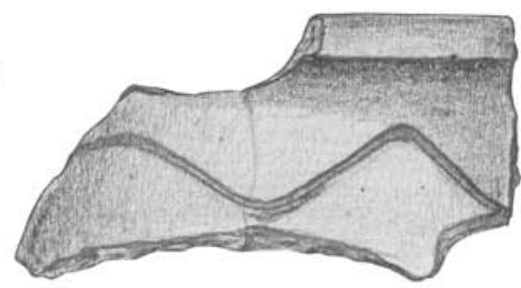

13.10/7.2.6.
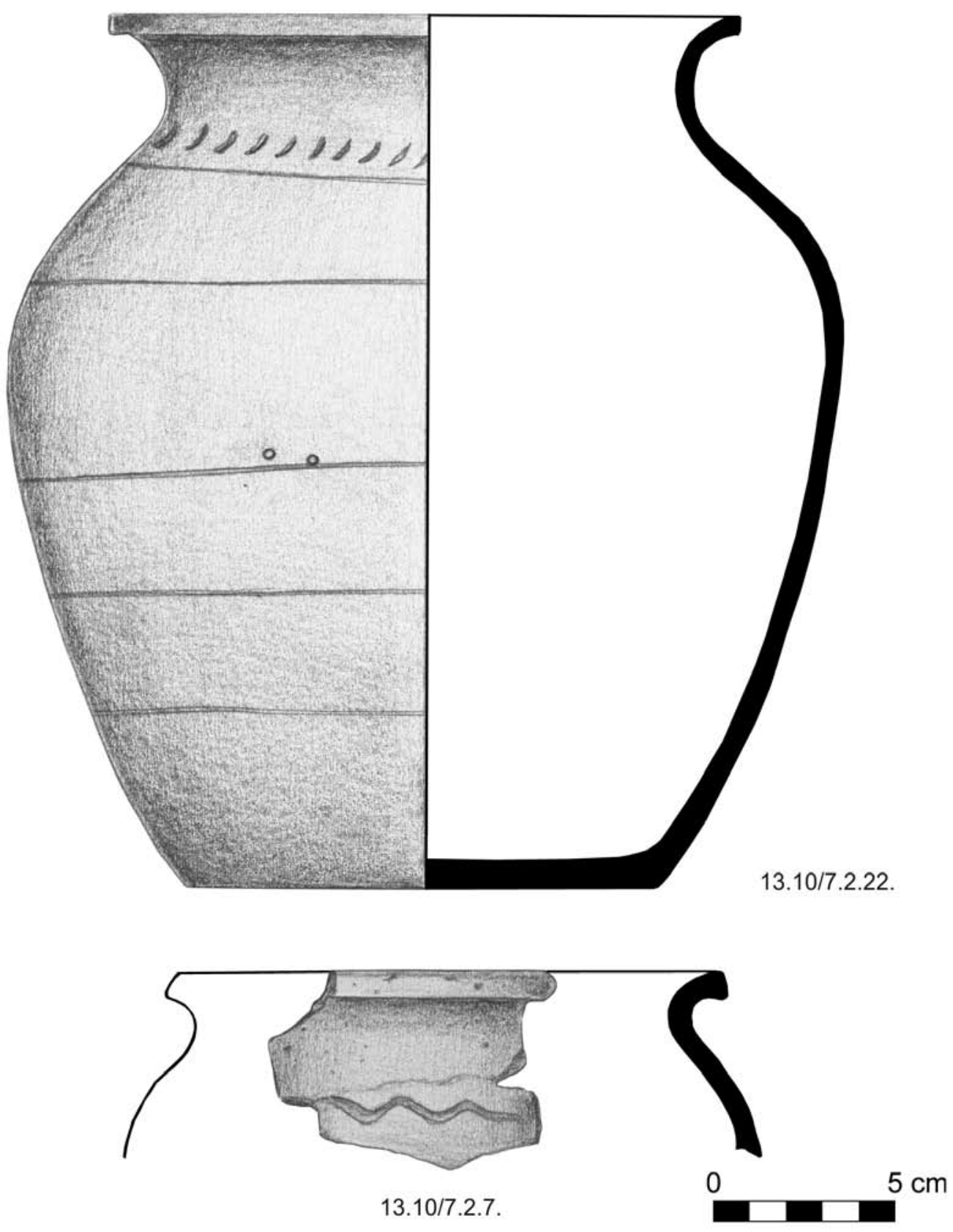

6. tábla: $67 / 5$ lelőhely, leletek a 7. objektumból 

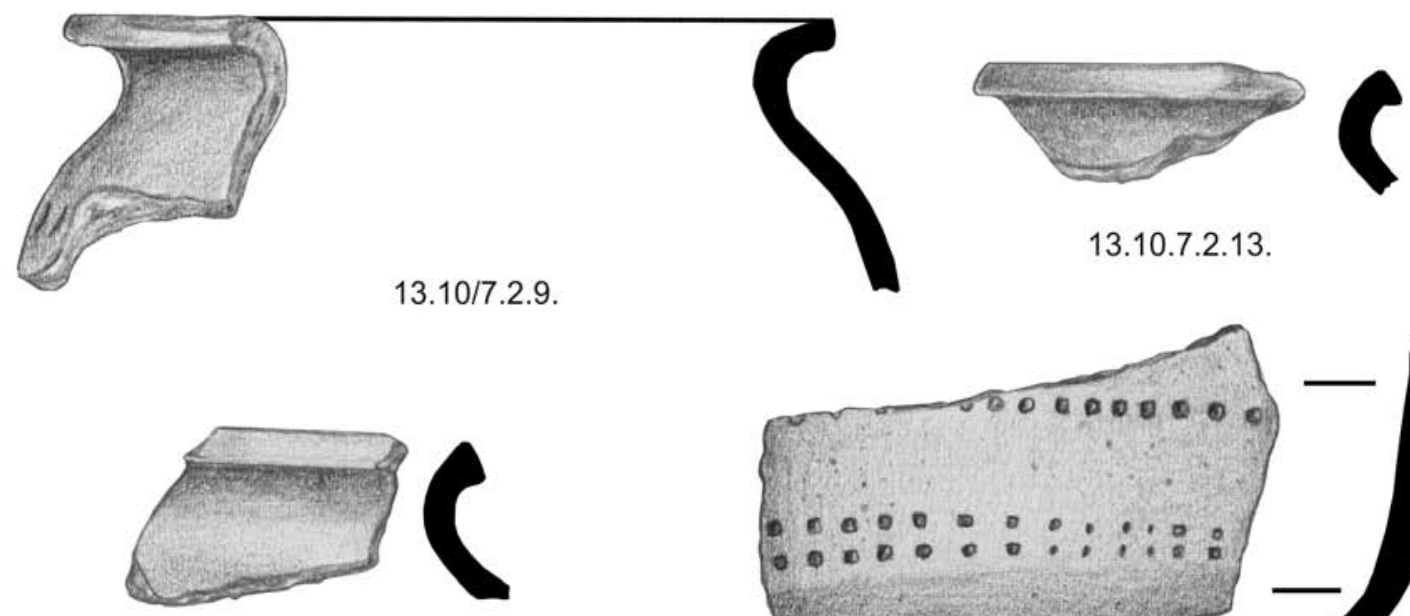

13.10.7.2.13.

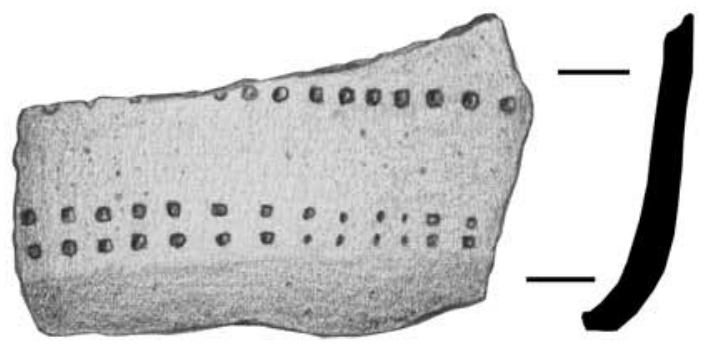

13.10/7.2.12.

13.10/230.1.1.
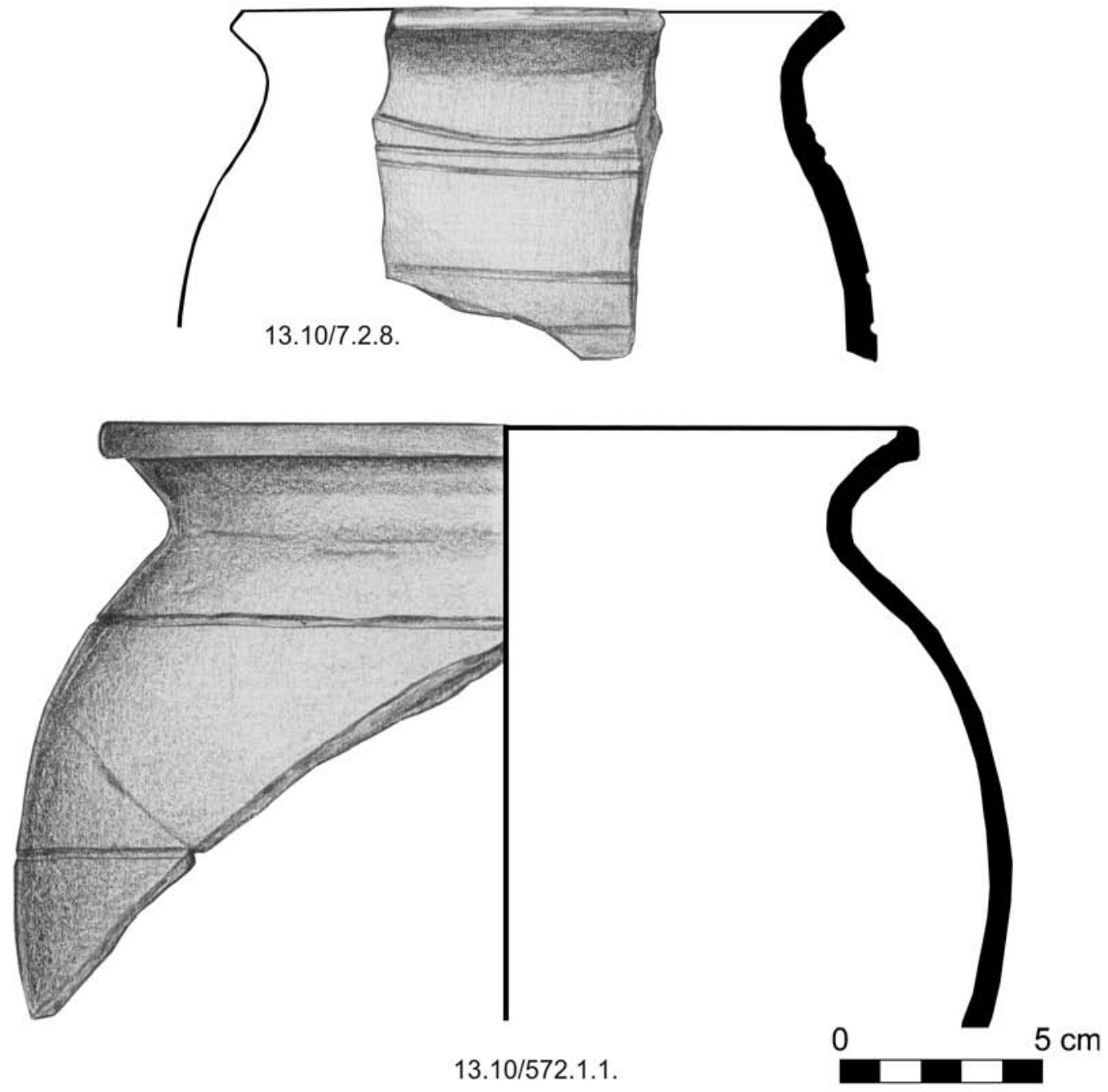

7. tábla: 67/5 lelőhely, leletek a 7., 230., 572. objektumból 


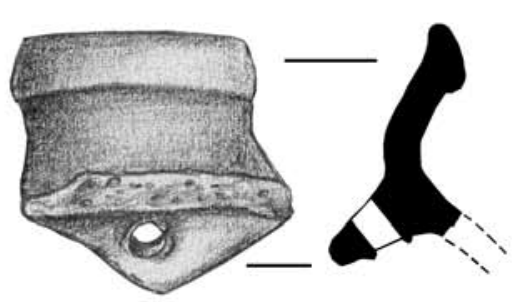

13.9/435.3.1.

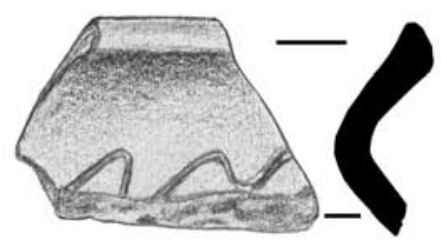

13.9/437.3.1.

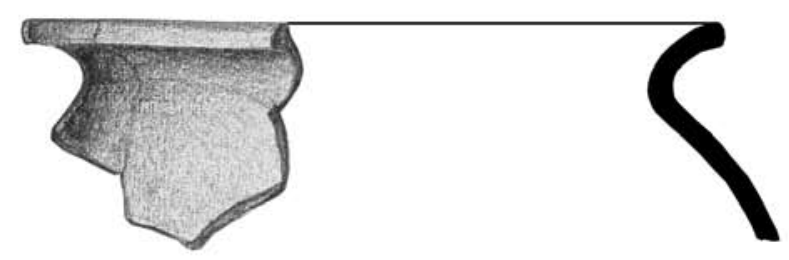

13.9/435.3.2

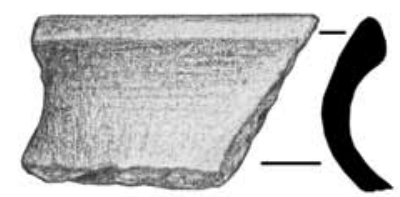

13.9/438.1.1.

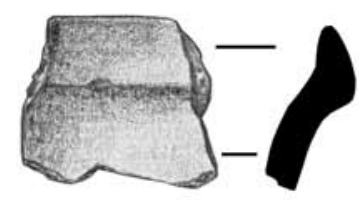

13.9/438.1.4.

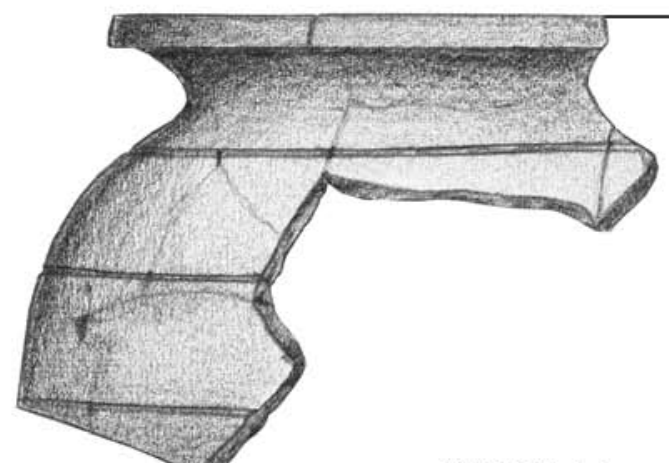

13.9/435.4.4

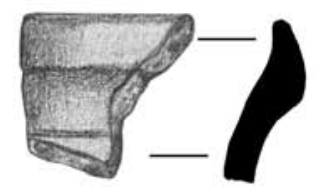

13.9/438.1.3.

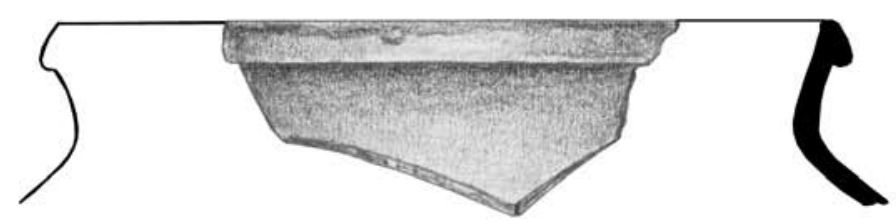

13.9/538.7.1

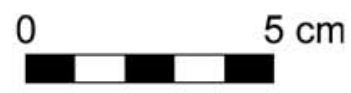

8. tábla: 67/4 lelöhely, leletek a 435., 437., 438. és 538. objektumból 


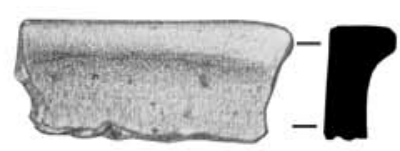

13.9/538.9.1.

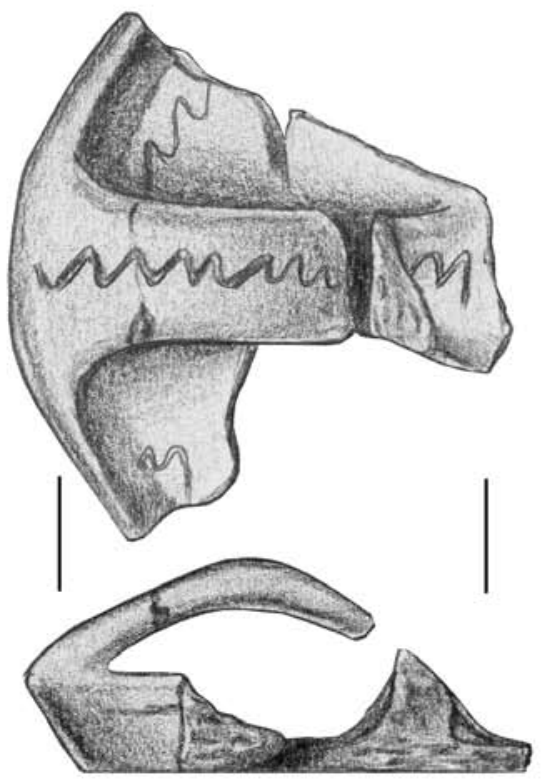

13.9/551.2.1.

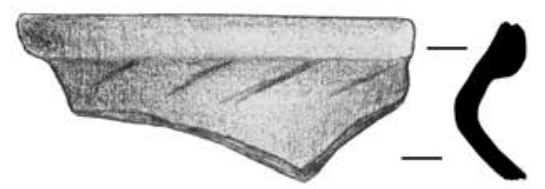

13.9/625.1.1.

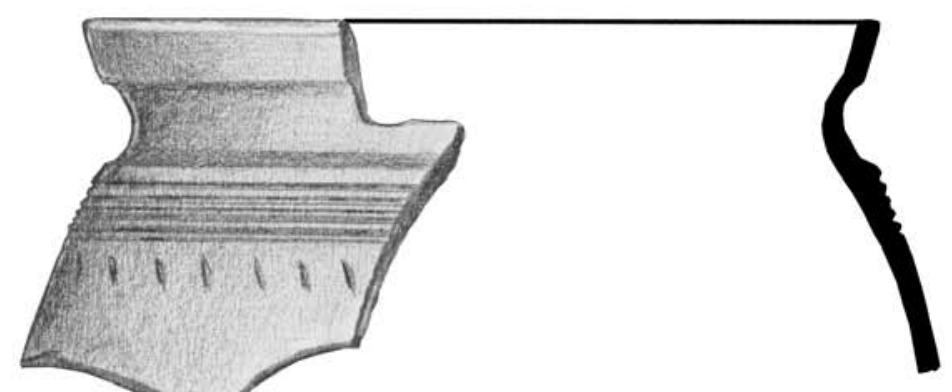

13.9/551.1.1

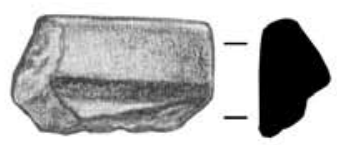

13.9/612.1.5

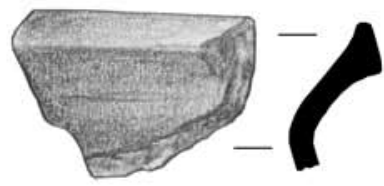

13.9/612.1.4

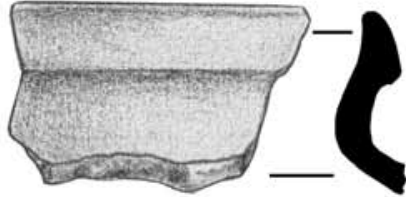

13.9/625.1.3
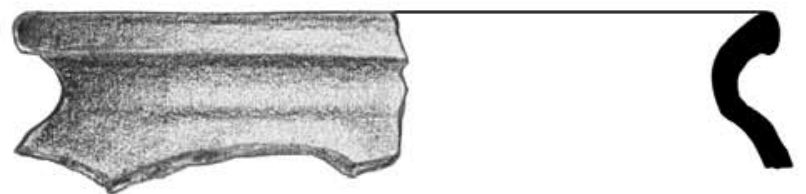

13.9/625.2.2

0 $5 \mathrm{~cm}$

9. tábla: 67/4 lelőhely, leletek az 538., 551., 612. és 625. objektumból 
4. obj.
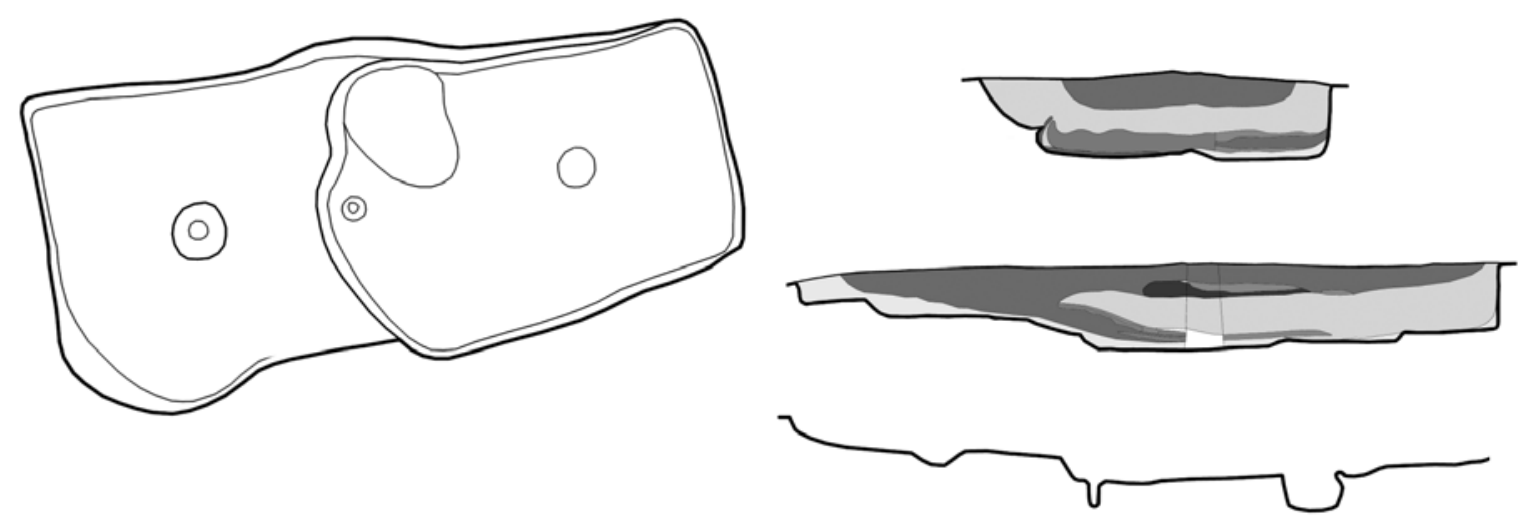

$5,7,16$. obj.
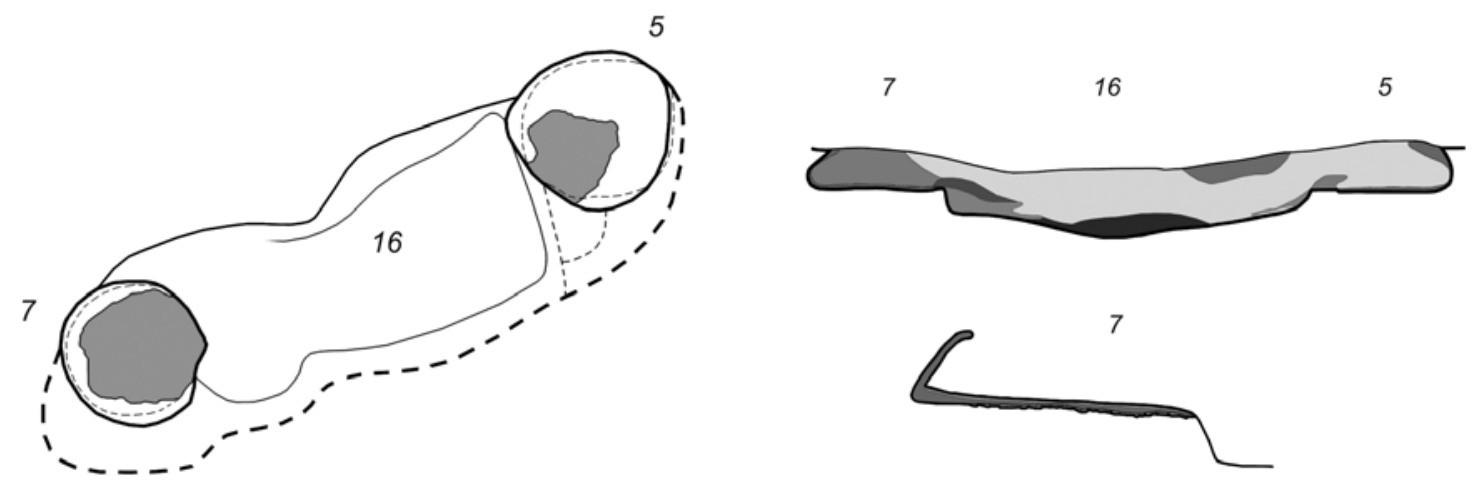

6. obj.

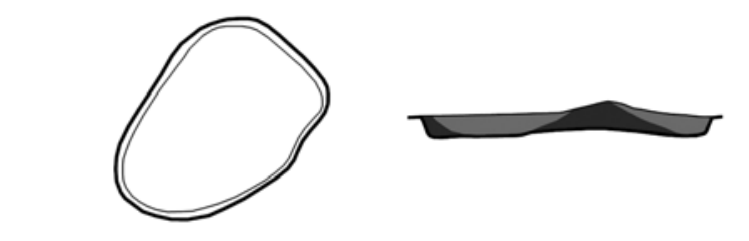

19. obj.
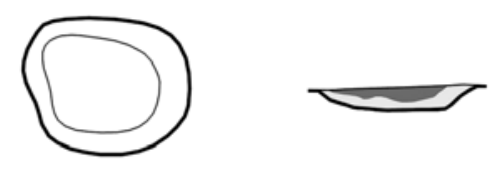

347. obj.

230. obj.

$\bigcirc$
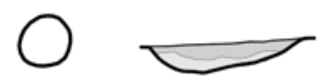
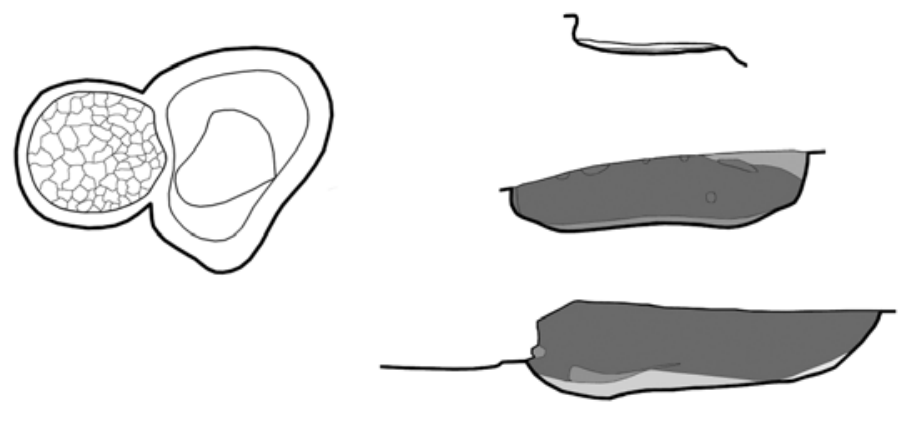

10. tábla: 67/5 lelöhely 4- 7., 19., 230., 347. objektum 
435, 436, 437, 438. obj.

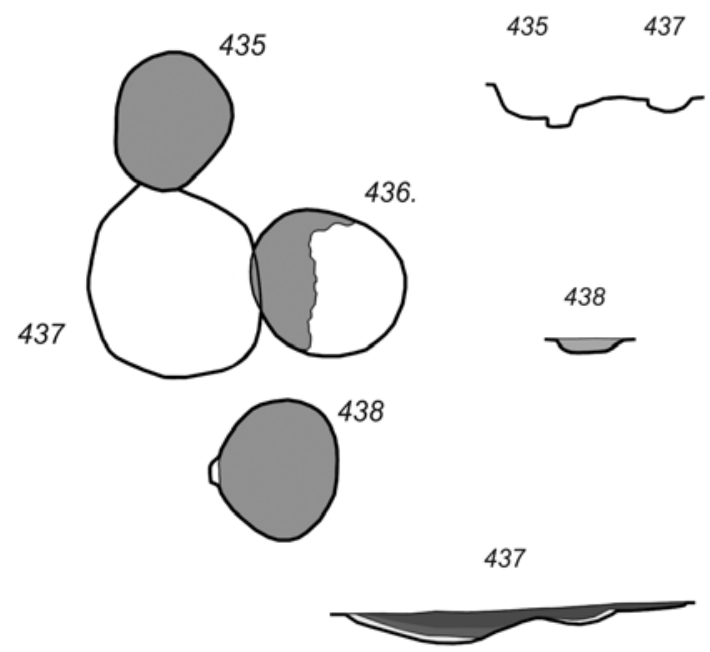

551. obj.
538. obj.
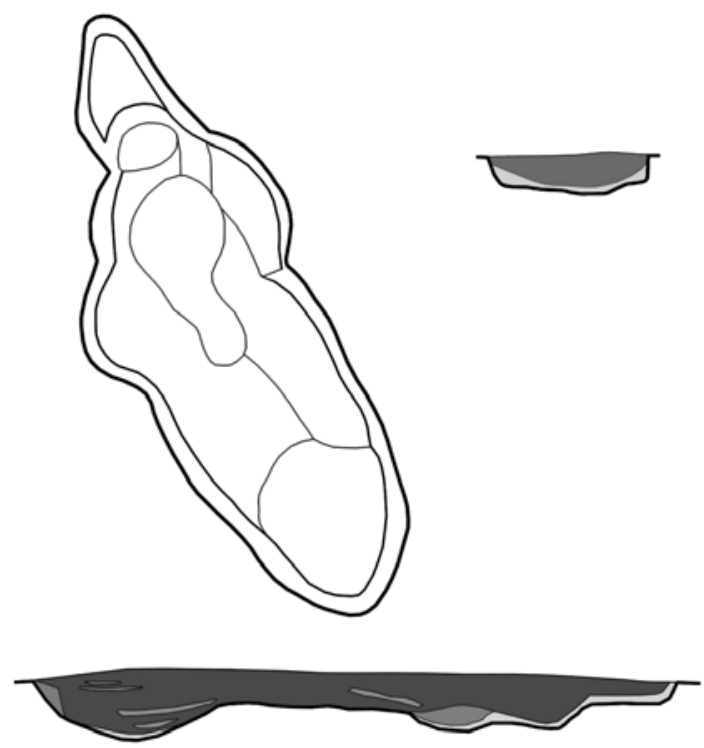

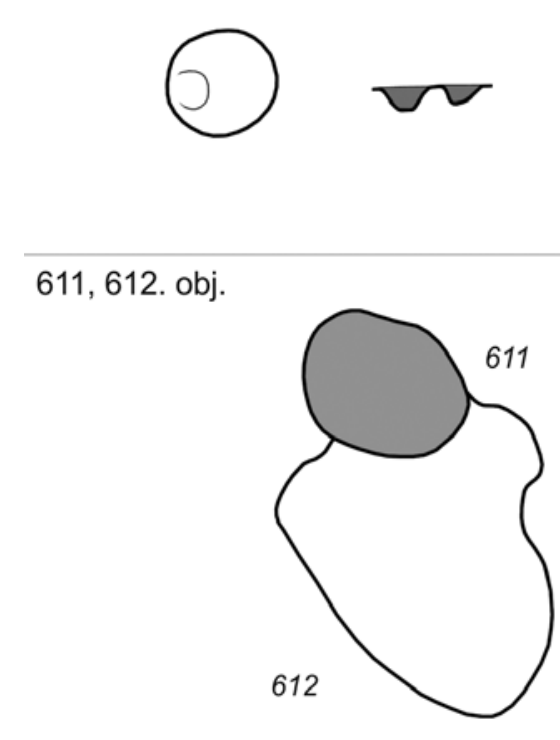

572. obj.

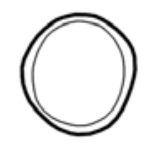

612

611

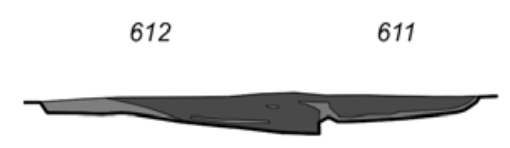

656. obj.
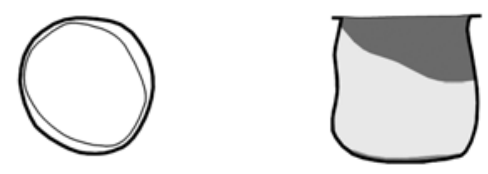

11. tábla: 67/4 lelöhely 435-438., 538, 611-612., 624-625. 656. 67/5 lelöhely 551. és 572. objektum 

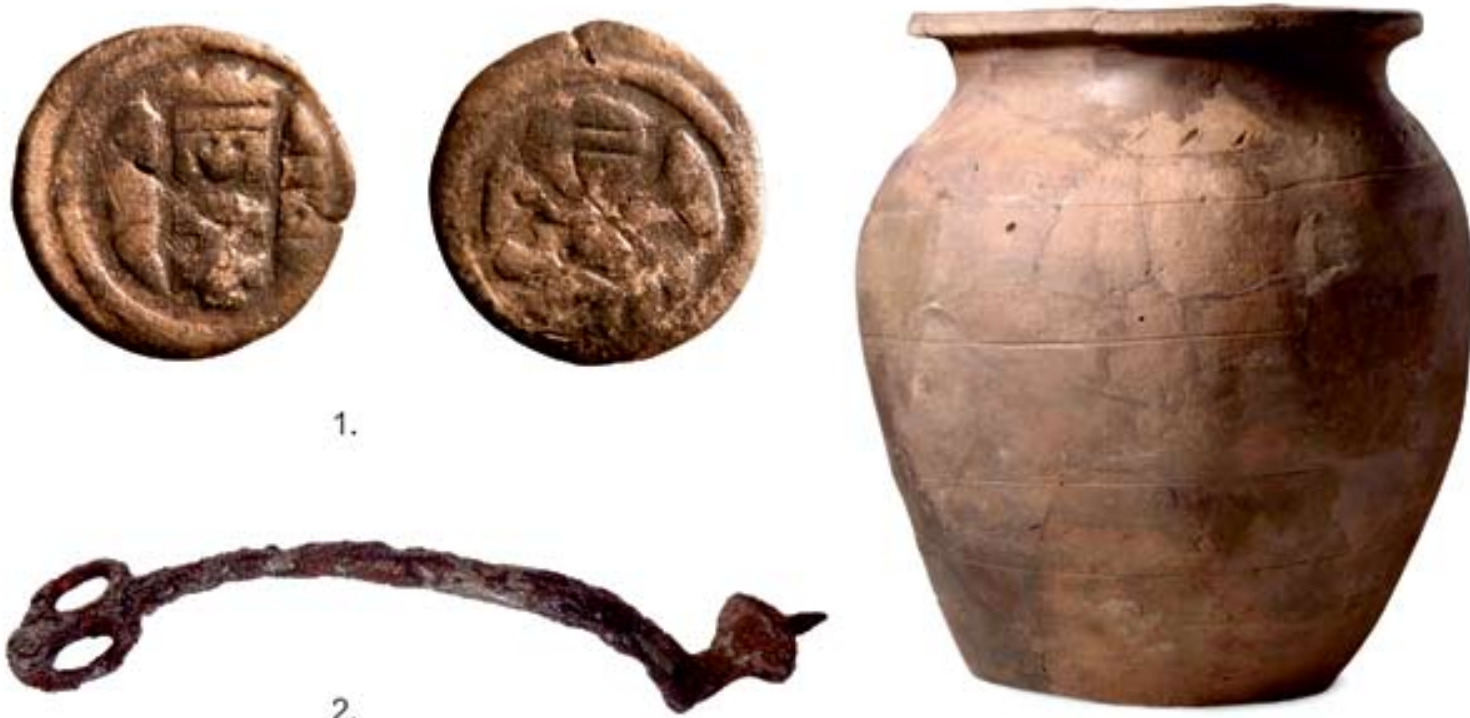

2.

3.

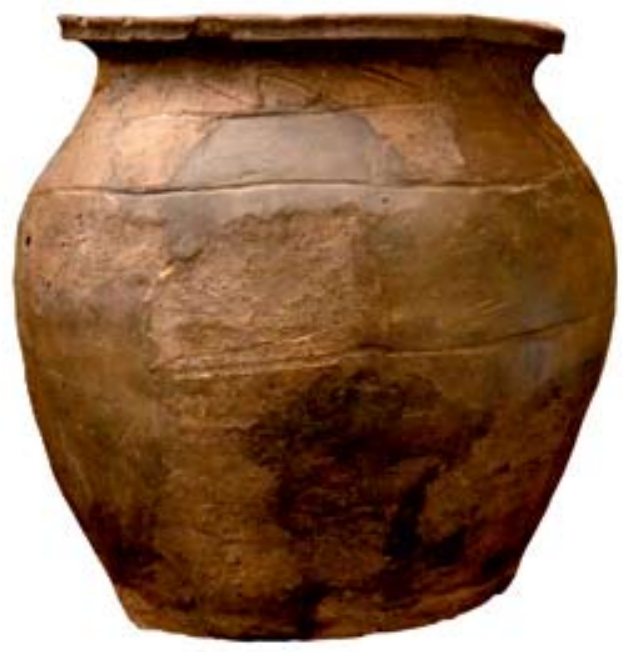

4.

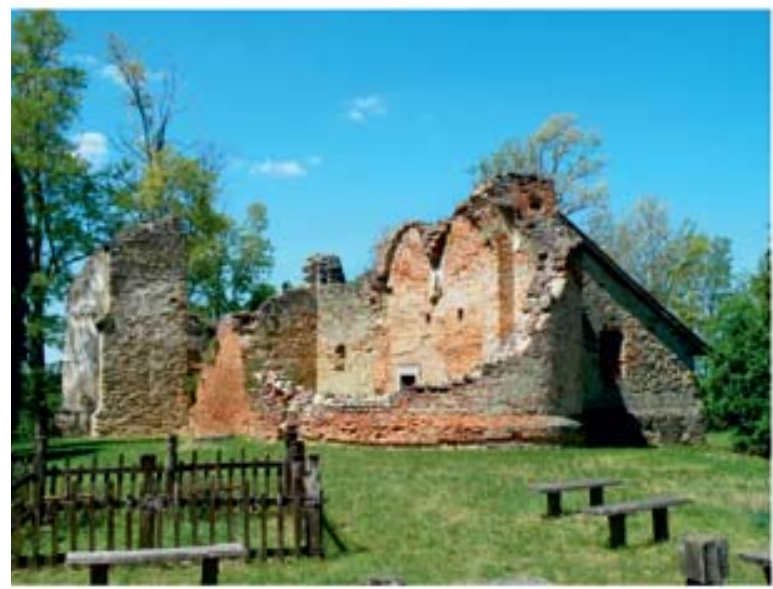

6.

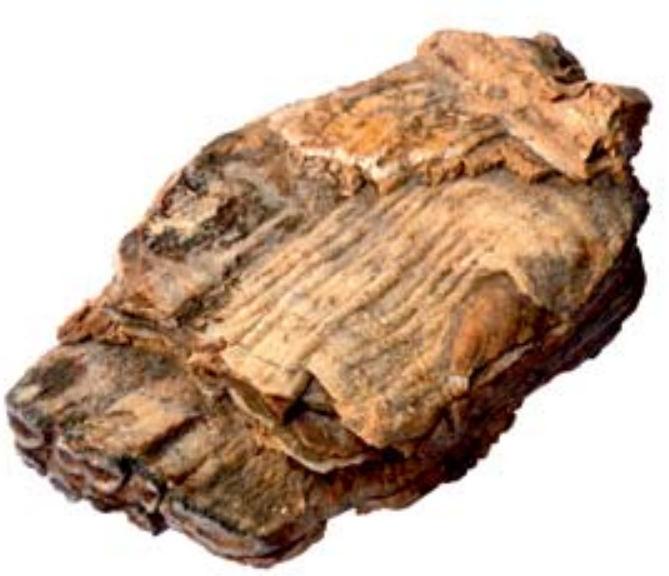

5.

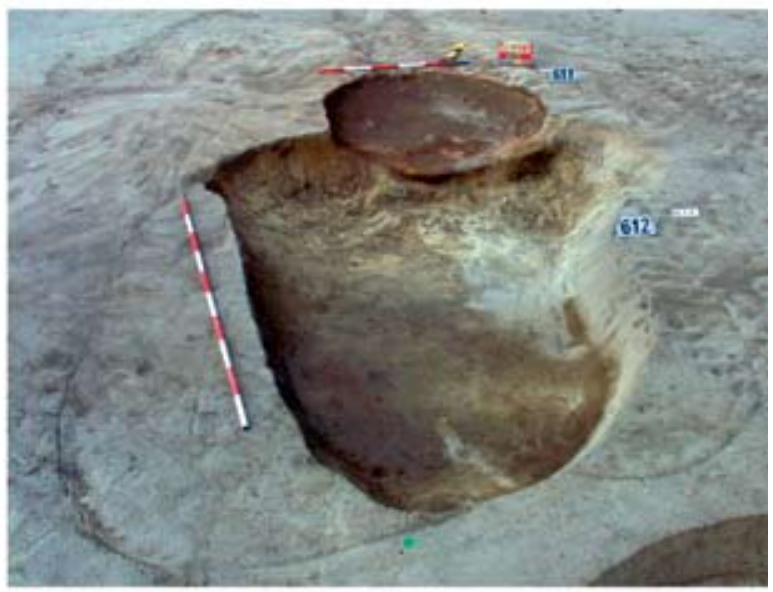

7.

12. tábla: 1 kép: IV. Béla uralkodása alatt vert pénz, 2. kép: Sarkantyú a 4. épület betöltéséből, 3. kép: Edény a 7. kemence platnija alól, 4. kép: Edény az 5. kemence platnija alól, 5. kép: Mamutfog a 4. épület betöltéséböl, 6. kép: A rádi templom romjai, 7. kép: Árpád-kori külső kemence (611-612. objektum) 
